\title{
Modeling innovative aquaponics farming in Kenya
}

\author{
Klaas Hielke Dijkgraaf ${ }^{1} \cdot$ Simon Goddek $^{1} \cdot$ Karel J. Keesman $^{1}$
}

Received: 28 October 2018 / Accepted: 9 May 2019 / Published online: 27 May 2019

(C) The Author(s) 2019

\begin{abstract}
Designing an aquaponic system is based on guidelines found in literature. However, it is uncertain whether these guidelines are optimal in the case of a multi-loop decoupled aquaponic system (DAPS) with an anaerobic digester. The objective of this study was to build and analyze a model of a multi-loop DAPS with digester, and use it to review system performance in terms of sustainability criteria. In particular, the computer-aided case study of a multi-loop DAPS in Nairobi (Kenya) was performed to evaluate the design, in terms of water and nutrient use efficiencies and energy consumption. Furthermore, the model was used to perform a sensitivity analysis, and to perform further optimization of the design. The findings of a modelbased design clearly indicate that aquaponic system design guidelines, as found in literature, do not necessarily lead to an optimal system design of a multi-loop DAPS with digester. The main reason for this deviation is the presence of a digester in the multi-loop DAPS. Moreover, the results showed that nutrient concentration ranges have a large impact on the performance of any aquaponic system, in terms of sustainability, since these ranges determine when dilution or supplementing of the nutrient solution is needed. Optimization of the system design resulted in a nutrient use efficiency (NUE) of nitrogen of $77.74 \%$, a NUE of phosphorus of $95.09 \%$, a water use efficiency of $99.74 \%$, and a feeding rate ratio of $5.19 \mathrm{~g} \mathrm{~m}^{-2}$ day $^{-1}$.
\end{abstract}

Keywords Anaerobic digester · Aquaponics · Mobilization · Modeling · Optimization · Remineralization $\cdot$ Sensitivity analysis
Abbreviations
COD Chemical oxygen demand
DAPS Decoupled aquaponic system
DM Dry matter
HPS Hydroponic system

Simon Goddek

simon.goddek@wur.nl

Karel J. Keesman

karel.keesman@wur.nl

1 Biobased Chemistry \& Technology, Wageningen University, P.O. Box 17, 6700 AA Wageningen, The Netherlands 
KPI Key performance indicator

MBBR Moving bed biofilm reactor

NUE Nutrient use efficiency

RAS Recirculating aquaculture system

TAN Total ammonia nitrogen

TSS Total suspended solids

\section{Introduction}

Increasing worldwide population is a leading cause of challenges, such as maintaining food security, increasing pollution, and decreasing resources (Qadir et al. 2007; Cordell et al. 2009; UN 2012). Water, nutrients, and energy are becoming more and more scarce, leading to insufficient food production. Hence, there is a need for sustainable food production methods. Aquaponics can play a vital role in addressing the issue of sustainable food production.

Aquaponics is a combination of recirculating aquaculture system (RAS) and a hydroponic system (HPS) (Timmons and Ebeling 2010), in which plants are grown without soil. An unwanted trait of a RAS is the accumulation of waste, consisting of organic matter and nutrients, to levels that are toxic to fish (Rakocy et al. 2006). The accumulation of organic materials and nutrients has to be counteracted by mechanical filters and biofilters. Mechanical filters are used to partly capture the solid waste in the fish water, such as feces or uneaten feed. Biofilters are used to partly remove soluble nitrogenous compound waste from the fish water, such as ammonia and nitrite which can be toxic to fish (Timmons and Ebeling 2010). In hydroponics, nutrients are dissolved in water, as opposed to conventional plant production where nutrients are added to the soil. Substrates, such as rock wool, if necessary combined with a wire, provide the stability that is normally provided by soil.

By combining aquaculture with hydroponics, the waste of the RAS can be used as a nutrient source for the hydroponic system (HPS), thus reducing the need for adding nutrients from an external source. In a RAS, fish water is bled off and fresh water is added to ensure proper water quality for the fish. In a conventional or coupled aquaponic system, water circulates between the fish and the plant compartment (Palm et al. 2014, 2018). Plants assimilate nutrients from the water, lowering nutrient concentrations, and therefore ensuring proper water quality for the fish. A disadvantage of a conventional aquaponic system is that water characteristics in the fish and plant compartment are identical. Therefore, optimal conditions can only be achieved if optimal conditions for fish and plants are identical, which is rarely the case (Timmons and Ebeling 2010) as typically optimal pH, nitrogen concentrations, etc. differ. Another disadvantage of a conventional aquaponic system is that nutrients cannot accumulate in the RAS as they are consistently removed by filters, unless nutrients in solid waste are mineralized (Rakocy et al. 2007). Therefore, the nutrient concentrations in the water flow from the RAS to the HPS are relatively low compared with nutrient concentrations in conventional hydroponic nutrient solutions (Kloas et al. 2015; Goddek and Keesman 2018).

A different approach is a decoupled aquaponic system (DAPS), in which water is not circulating between the RAS and HPS, but only flows from the RAS to the HPS. The RAS is subsequently topped off with fresh water. The aforementioned disadvantages of a conventional aquaponic system are not present in a DAPS (Kloas et al. 2015, Goddek \& Vermeulen 2018). However, water usage is higher than in a coupled aquaponic system. Plant assimilation is no 
longer used as a means of lowering nutrient concentrations to achieve fish water requirements. Consequently, more fresh water is necessary to meet the requirements of the fish water.

Sustainability of a DAPS can be improved by introducing an anaerobic digester to the system, making it a multi-loop system. The captured solids (fish sludge), from the mechanical filter, consisting of organic, chemically oxidizable matter, can be used as feedstock for an anaerobic digester. Produced biogas can be converted into electricity, which can be used to power the multi-loop DAPS. The solid waste sludge of the anaerobic digester can be used as fertilizer. The liquid residual waste stream from the anaerobic digester can be sent to the plants. This effluent has a positive impact on plant growth since the digestion process remobilizes nutrients which are present in the effluent (Goddek et al. 2016).

Several scholars (Karimanzira et al. 2016; Reyes Lastiri et al. 2016, 2018) defined a model of a DAPS without a digester, with the intent to analyze system behavior under variable system designs. Consequently, the models could be used in designing the system or in finding optimal management and operational strategies. Yogev et al. (2016), Goddek and Keesman (2018), and Goddek and Körner (2019) defined a model of a multi-loop DAPS with digester, where the objective was to demonstrate the potential of a multi-loop DAPS with digester.

Typically, the design of aquaponic systems is based on guidelines such as suggested by Rakocy et al. (2006). There is still uncertainty, however, whether these guidelines are optimal in the case of a multi-loop DAPS. This question, to the best of our knowledge, has not been answered in literature yet. The objective of this study was to build and analyze a model of a multi-loop DAPS with digester in Kenya, and use it for the evaluation of the system's performance in terms of efficient use of nutrients, water, and energy. A computer-aided case study of a multi-loop DAPS in Nairobi (Kenya) was performed, in which the mathematical model was used to review the aforementioned multi-loop DAPS design, in terms of water and nutrient use efficiencies and energy consumption, and to perform further optimization of the design.

\section{Materials and methods}

\section{System and process description}

Kikaboni Farm is located south-west of Nairobi, Kenya, and consists of a RAS, an anaerobic digester, and an HPS. Design parameters of this system that were considered in this research study are the planting area in the HPS and the maximum stocking density in the RAS. An overview of the system is shown in Fig. 1.

\section{Recirculating aquaculture system}

The RAS is indoors and has a total volume of $50 \mathrm{~m}^{3}$, equally divided over four fish tanks. Fish production is staggered, meaning that fish age is different for every tank. Maximum stocking density in the RAS is designed at $40 \mathrm{~kg} \mathrm{~m}^{-3}$, which indicates the point at which all fish in the tank are harvested. Nile tilapia (Oreochromis niloticus) enter the RAS as 1-in. fingerlings and grow for 200 days, meaning that every 50 days, one tank is harvested and restocked with fingerlings. Two $1.1 \mathrm{~kW}$ electric water pumps and gravity are driving forces for transport of water between system elements. 


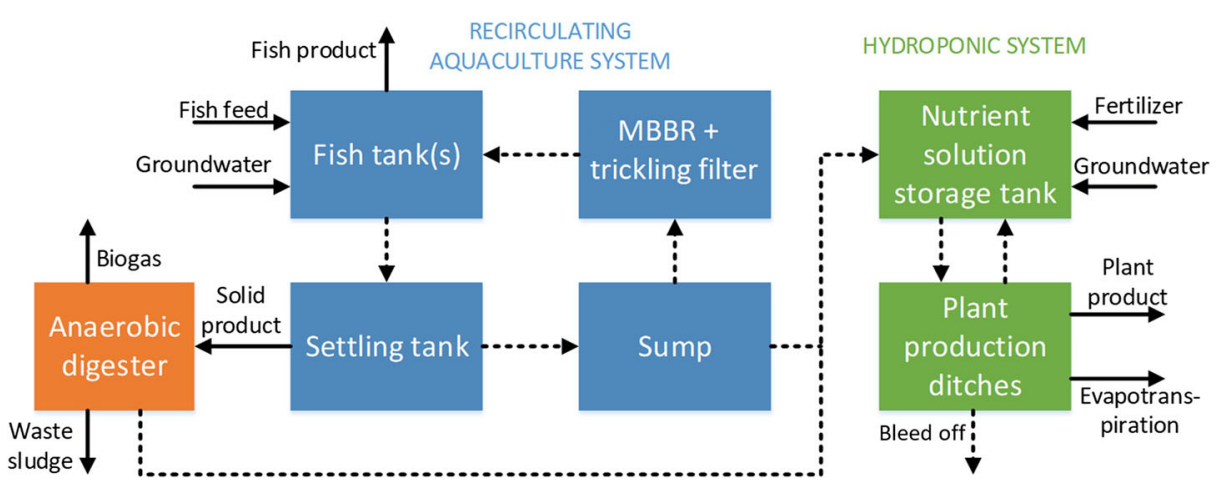

Fig. 1 An overview of the DAPS of the Kikaboni farm with all relevant material flows. Dashed lines indicate flows of water, containing nutrients

Determination of the fish growth is required to calculate feed input, which is an essential control variable to compute nutrient quantities going into the system. Feed contents and other parameters that were used in the model and related to fish feed can be found in Table 1. Knowing that the $\mathrm{N}$ content of protein is $16 \%$ (Yogev et al. 2016), the $\mathrm{N}$ content of fish feed can be computed.

To quantify fish growth, the model of Timmons and Ebeling (2010) was used. Fish length growth and subsequently weight gain was calculated using species-specific constants and water temperature. Required feed input was calculated using a species-specific feed conversion ratio (FCR). Timmons and Ebeling (2010) state that the FCR is variable depending on fish weight (WT). The following sigmoid function for the FCR was defined:

$$
\mathrm{FCR}=1.29+\frac{-0.548}{1+\left(\frac{\mathrm{WT}}{121}\right)^{6.51}} .
$$

Thus, the FCR can be calculated using fish weight (in grams) as input.

Feed eaten by fish is metabolized, meaning that nutrients in the eaten feed are excreted or converted into body mass. Nutrients are excreted in solid form when they are present in fish feces, or in soluble form when they are present in fish urine or excreted through the gills. All parameters corresponding with the fish metabolism are shown in Table 2.

Successful tilapia aquaculture requires water characteristics that meet certain ranges as presented in Table 3.

A moving bed biofilm reactor (MBBR) and a trickling filter are present in the RAS, acting as a biofilter and a means for gas exchange. One $0.75 \mathrm{~kW}$ roots blower is responsible for pumping air into the MBBR. It is assumed that the biofilter is large enough to remove $98 \%$ of

Table 1 Fish feed contents and other related parameters that are used in the model

\begin{tabular}{llll}
\hline Parameter & Value & Unit & Source \\
\hline DM content & $90 \%$ & Mass fraction & (FAO 2018) \\
Protein content & $35 \%$ & Mass fraction & (Craig and Helfrich 2002) \\
P content & $1.5 \%$ & Mass fraction & (Craig and Helfrich 2002) \\
COD content & 1.4 & $\mathrm{~g} \mathrm{O}_{2} \mathrm{~g}^{-1} \mathrm{DM}$ & (Meriac 2014) \\
Uneaten feed & $18 \%$ & Mass fraction & (Neto and Ostrensky 2015) \\
Feed to TSS & $25 \%$ & Mass fraction of food per day & (Timmons and Ebeling 2010) \\
\hline
\end{tabular}


Table 2 Parameter values corresponding to fish metabolism as used in the model, see also Eck et al. (2019)

\begin{tabular}{llll}
\hline Parameter & Value (\%) & Description & Source \\
\hline Fish retention of N & 35 & Fraction of N in eaten feed & (Neto and Ostrensky 2015) \\
Solid excretion of N & 13 & Fraction of N in eaten feed & (Neto and Ostrensky 2015) \\
Soluble excretion of TAN & 33 & Fraction of N in eaten feed & (Neto and Ostrensky 2015) \\
Fish retention of P & 28 & Fraction of P in eaten feed & (Neto and Ostrensky 2015) \\
Solid excretion of P & 37 & Fraction of P in eaten feed & (Neto and Ostrensky 2015) \\
Soluble excretion of P & 17 & Fraction of P in eaten feed & (Neto and Ostrensky 2015) \\
COD of solid excretion & 14 & Fraction of COD of eaten feed & (Meriac 2014) \\
COD of soluble excretion & 53 & Fraction of COD of eaten feed & (Meriac 2014) \\
\hline
\end{tabular}

TAN, and all steps of the nitrification process are taking place. In the case that maximum allowed concentrations are surpassed, RAS water is diluted by moving RAS water from the sump to the HPS, and topping the RAS off with fresh water.

RAS water temperature is higher than the average ambient temperature in Nairobi (WorldWeatherOnline 2017), meaning that heat will be lost to the surroundings. Furthermore, $18^{\circ} \mathrm{C}$ groundwater flowing into the RAS needs to be heated to meet the required temperature. Computing heat loss requires data on the RAS buildings' climate, and fish tank material characteristics, which are not available. Unreported estimations of these heat losses indicated that these are negligible compared with the heating requirement of inflowing groundwater. Heating water using solar energy increases the systems' self-sufficiency. In this case, solar collectors were installed. During this research study, it was assumed that the solar collectors have a thermal efficiency of 50\% (Jamar et al. 2016).

\section{Hydroponic system}

The total planting area of the hydroponic system is covering $1500 \mathrm{~m}^{2}$. Crops are grown in troughs with a water depth of $0.5 \mathrm{~m}$, in a plastic tunnel greenhouse. Total water volume of the HPS was determined based on total planting area and water depth in the troughs. Lettuce, Lactuca sativa, is grown in staggered production with a cycle duration of 75 days. Tomato, Solanum lycopersicum, is grown in staggered production with a cycle duration of 145 days. Lettuce and tomato each covers $750 \mathrm{~m}^{2}$ of the $1500 \mathrm{~m}^{2}$ total planting area.

Evapotranspiration was assumed to be proportional with the amount of nutrients taken up by the plant for growth. Previous studies have used the FAO Penman-Monteith equation (Allen et al. 1998) to calculate the reference evapotranspiration rate $E T_{0}$ (Zolnier and Gates 2004; Qiu et al. 2013; Goddek and Keesman 2018). $E T_{o}$ is dependent on geographical location (Nairobi, $1^{\circ} 28^{\prime} \mathrm{S} ; 36,42^{\prime} \mathrm{E}$ ), air temperature, relative humidity, solar radiation, and greenhouse properties. Solar radiation values were obtained from Onyango and Ongoma (2015), who

Table 3 Water requirements for tilapia considered in the model

\begin{tabular}{llll}
\hline Requirement & Value & Unit & Source \\
\hline Temperature & $27-30$ & ${ }^{\circ} \mathrm{C}$ & (El-Sayed 2006) \\
$\mathrm{pH}$ & $7-9$ & - & (Ross 2000) \\
Ammonia $\left(\mathrm{NH}_{3}-\mathrm{N}\right)$ & $<0.1$ & $\mathrm{mg} \mathrm{L}$ & (El-Sayed 2006) \\
Nitrite $\left(\mathrm{NO}_{2}-\mathrm{N}\right)$ & $<5$ & $\mathrm{mg} \mathrm{L}^{-1}$ & (DeLong et al. 2009) \\
Nitrate $\left(\mathrm{NO}_{3}-\mathrm{N}\right)$ & $<400$ & $\mathrm{mg} \mathrm{L}^{-1}$ & (DeLong et al. 2009) \\
\hline
\end{tabular}


estimated solar radiation for Nairobi using data from a local weather station. Temperature and relative humidity were monthly average values for the period 2009-2016, which were retrieved from the web (WorldWeatherOnline 2017). The FAO Penman-Monteith equation demands a minimum and maximum average relative humidity, whereas the previously mentioned website only provides the average relative humidity. Minimum and maximum average humidity were approximated by respectively subtracting and adding $10 \%$ to the average relative humidity. Data from 2009 to 2016 was used to compute average weather data for 1 year, and can be found in the Appendix A. Greenhouse properties are specific for the Kikaboni greenhouse, and are also shown in Appendix A. To calculate the crop-specific evapotranspiration rate $\left(E T_{c}\right), E T_{o}$ is multiplied by the single crop coefficient $\left(K_{c}\right)$ :

$$
E T_{c}=E T_{0} \cdot K_{c} .
$$

$K_{c}$ is dependent on crop stage, as can be seen in Fig. 5 in Appendix A. $E T_{0}$ was calculated for every month. Subsequently, the crop-specific evapotranspiration for an entire crop cycle was calculated using Eq. 2, with corresponding $E T_{0}$ value. In the case of lettuce, the crop-specific evapotranspiration $\left(E T_{c}\right)$ during 75 days was calculated. From this, the average daily cropspecific evapotranspiration rate was determined, which is justified due to the fact that crop production is staggered. Because both $E T_{0}$ and $K_{c}$ are varying within 1 year, the crop-specific evapotranspiration will also fluctuate throughout the year, as seen in Fig. 2. Data was smoothed to improve the resemblance with reality.

It was assumed that crop production for both tomato and lettuce is constant when nutrient concentrations are within optimal ranges. From previous research, it can be concluded that there is significant variation in advices for the optimal concentrations of nutrients in the nutrient solutions of hydroponic systems. In our system, the nutrient solution is based on RAS water complemented with nutrients or diluted with fresh water to promote optimal growth (Table 4). Furthermore, optimal nutrient concentrations are crop dependent. In the HPS of the Kikaboni farm, both lettuce and tomato are grown using the same nutrient solution. The nutrient solution pre-specified bounds were

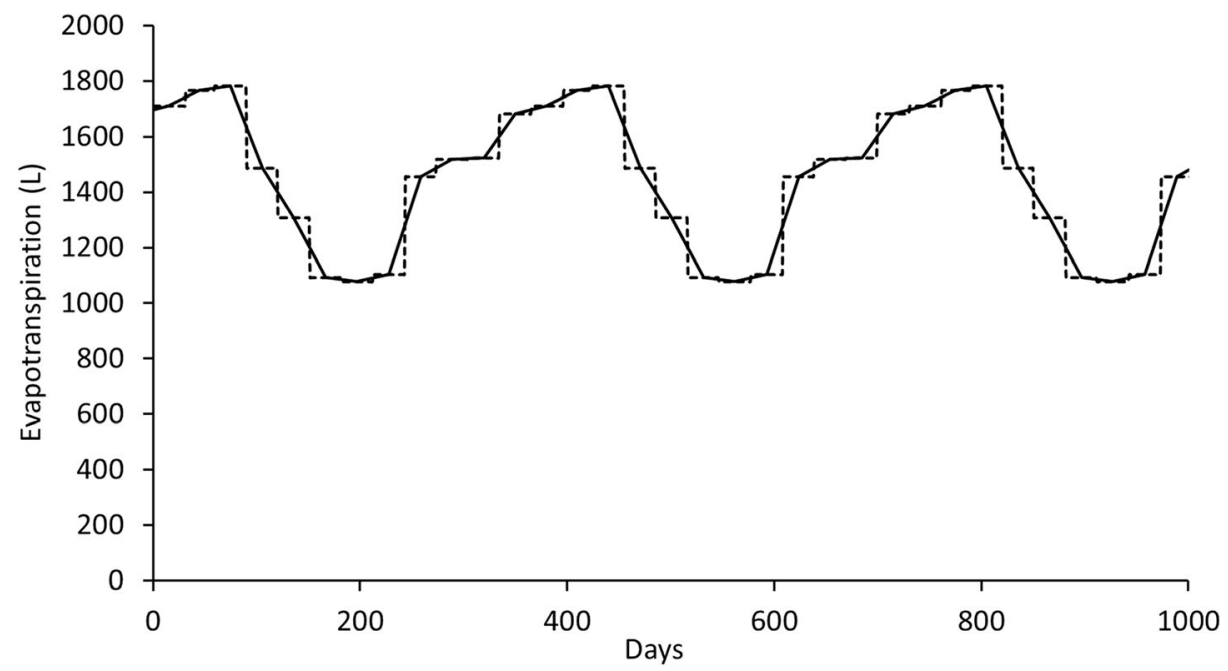

Fig. 2 Evapotranspiration in the nominal situation of the Kikaboni farm DAPS, in which day 0 is January 1 st. Evapotranspiration is calculated on a monthly basis (dashed line) but smoothed to represent reality (solid line) 
Table 4 Requirements for $\mathrm{N}$ and $\mathrm{P}$ concentration in the nutrient solution used on the Kikaboni farm for lettuce and tomato production

\begin{tabular}{ll}
\hline Nutrient & Bounds \\
\hline $\mathrm{NO}_{3}-\mathrm{N}$ & $100-200 \mathrm{mg} \mathrm{L}^{-1}$ \\
$\mathrm{P}$ & $32-48 \mathrm{mg} \mathrm{L}^{-1}$ \\
\hline
\end{tabular}

set in a way that satisfies both the nutrient concentration requirements of lettuce and tomato and is in line with advices found in literature (Letey et al. 1982; Jones 2004; Santos et al. 2004; Sonneveld and Voogt 2009; Resh 2015; Schmautz et al. 2016; Suhl et al. 2016).

For every day, the volume of dilution requirement is calculated. During dilution, the calculated volume of nutrient solution is removed from the system and replaced with groundwater. Obviously, replacing with groundwater instead of replacing with RAS water means that water is more efficiently used since nutrient concentrations in RAS water are higher than nutrient concentrations in groundwater. The volume of nutrient solution that is removed and replaced with groundwater in case of dilution is referred to as the replacement volume.

\section{Anaerobic digester}

The residual fish sludge stream from the settling tank was assumed to have a small total solids content of $2.25 \mathrm{wt} \%$ (Mirzoyan et al. 2010). Mesophilic microorganisms break down the biodegradable material in this stream under the absence of oxygen. Since mesophilic microorganisms are used, a moderate temperature of 20 to $40^{\circ} \mathrm{C}$ (Chernicharo 2007) is required in the digester, meaning that no additional heating is required. During anaerobic digestion, biogas is formed, of which the main compound is methane, which can be used as fuel for a power generator. Several authors have used mesophilic anaerobic digestion of fish sludge to produce methane (Lanari and Franci 1998; Gebauer 2004; Gebauer and Eikebrokk 2006). From these studies, it can be concluded that a methane production of $0.15 \mathrm{~m}^{3}$ per kilogram COD can be expected. The efficiency of the generator was assumed to be $35 \%$ (de Mes et al. 2003). The amount of net energy produced by the generator was found by multiplying the generators' efficiency by the heat of combustion of methane. Based on the enthalpy reaction of the combustion of methane, the molar mass of methane, and the density of methane, it can be computed that the heat of combustion of methane is $35.0 \mathrm{MJ} \mathrm{m}^{-3}$. The electric energy that is produced is used to power the pumps and blower. If the amount of electric energy generated from biogas combustion is not sufficient, photovoltaic (PV) panels were assumed to be used for the generation of the remaining amount. The efficiency of these PV panels was assumed to be $15 \%$ since this is the average efficiency of commercially sold PV panels. The required amount of PV panels and solar collectors was computed using the aforementioned solar radiation values.

Apart from biogas, waste sludge and effluent are additional outgoing streams from the digester. Anaerobic digestion effluent is a water stream in which the remainder of the nutrients that are not used in the digestion process is present. These nutrients are mobilized due to remineralization taking place in the digester, meaning that they are readily available for the plants (Delaide et al. 2018; Goddek et al. 2016). Up to $90 \%$ of $\mathrm{P}$ going into the digester can be present in the effluent (Jung and Lovitt 2011). Based on Goddek et al. (2018), it was assumed that $25 \%$ of ingoing nitrogen is present in the effluent. Solids present in the sludge will settle to the bottom of the digester, and effluent is captured from the top of the digester (Chernicharo 2007). Based on this fact, the assumption was made that $95 \%$ of the water present in the inflowing fish sludge is still present in the effluent outflow. 


\section{Model description}

\section{Model assumptions}

Mass, water, and energy balances in the form of ordinary differential equations were used to define a model (see Appendix B and C for details) for dynamic evaluation of water and nutrient use efficiencies and energy consumption. Water balances were set up for the RAS, the HPS, and the system as a whole (Eqs. 5-14). Nutrients that are taken into account are N and P. Both of these nutrients are macronutrients, where nitrogenous compounds may limit fish growth, and $\mathrm{P}$ is an exhaustible and scarce resource (Ragnarsdottir et al. 2011). Mass balances were set up for $\mathrm{NO}_{3}-\mathrm{N}$ (Eq. 15), TAN (Eq. 17), and P (Eq. 18) in the RAS, and $\mathrm{N}$ (Eq. 19) and P (Eq. 22) in the HPS. Furthermore, a mass balance of COD in the RAS was formulated in order to determine the biogas yield, as a result of anaerobic digestion of organic material (Eq. 23). An energy balance was formulated for the system as a whole (Eq.25). The water, all of the mass (N, P and COD), and energy balances are presented in Appendix B, accompanied by their corresponding explanations and justifications.

The differential equations were solved numerically in Microsoft Excel ${ }^{\mathrm{TM}}$ by using the Euler forward method, with a step size $\Delta t$ of 1 day. Solving differential equations numerically using the Euler forward method is a practical and simple way to approximate the solution of differential equations, at the cost of small deviations (errors) from the actual solution. The order of calculation steps taken to solve all differential equations can be found in Appendix C.

In this study, the following assumptions were made in order to make certain processes and issues negligible:

1. Whereas the settling tank will not trap all solids in the water, the remaining solids will settle in the sump of the RAS, which will be cleaned daily. The waste of this operation together with the solids from the settling tank will be put into the digester; thus, all solids will eventually end up in the digester, justifying the assumption of $100 \%$ solid removal.

2. Water temperatures in the RAS and HPS are constant.

3. Since fish and plant production are staggered, they are fluctuating around a constant as long as fish water requirements and nutrient solution requirements are met.

4. The volume of evapotranspiration water is multiplied by the concentration of a nutrient in the nutrient solution to approximate the amount of a nutrient taken up by the plants.

5. Nutrient concentration thresholds and limits for plants are constant throughout the entire plant cycle.

6. Water retention by fish and plants is neglected. Water leaving the RAS due to fish retention is no more than the maximum stocking density per 200 days, which in this case is $40 \mathrm{~kg} \mathrm{~m}^{-3}$ per 200 days. Water leaving the HPS due to plant retention of tomato plants is no more than $17 \mathrm{~kg} \mathrm{~m}^{-2}$ per 145 days (Schmautz et al. 2016), and due to plant retention of lettuce is no more than $7 \mathrm{~kg} \mathrm{~m}^{-2}$ per 75 days (Touliatos et al. 2016). Both these numbers are small compared with the loss of water due to evapotranspiration and bleed off, justifying the assumption.

7. Water entering the system due to its presence in the feed is neglected. DM content in the feed is high, and daily feed input is small compared with daily groundwater input.

8. $\mathrm{NO}_{3}-\mathrm{N}, \mathrm{TAN}, \mathrm{P}$, and $\mathrm{COD}$ concentrations in groundwater are zero. 


\section{Key performance indicators}

Since the model creates a large amount of data, key performance indicators (KPI) were identified to distinguish relevant model outputs. Model outputs were taken from day 150 to day 1149 , that is a period of 1000 days, starting on the first day when all fish tanks are stocked.

On the Kikaboni farm, nutrients are put into the system in the form of feed or supplements. Nutrients are lost in the waste sludge of the digester or in wastewater when dilution of the nutrient solution takes place. Given the sum of input streams and the sum of waste streams, the nutrient use efficiency of $\mathrm{N}$ and $\mathrm{P}$, but also of water, can be calculated from

$$
\text { Efficiency }=\frac{\sum \text { input }-\sum \text { waste }}{\sum \text { input }}
$$

In case of nutrients, Eq. 3 defines NUE (nutrient use efficiency). Equation 3 also applies to WUE (water use efficiency), in which input is all groundwater used and waste is the sum of disposed water during dilution of the nutrient solution and water present in the waste sludge of the digester. The NUE of N, the NUE of P, and the WUE were identified as KPIs.

The feeding rate ratio is used in aquaponics literature as a term to indicate the amount of fish feed required per day per planting area. Since it is widely used in aquaponics literature (Rakocy et al. 2004; Endut et al. 2010; Lennard 2012), this characteristic was also identified as a KPI.

\section{Model-based system design optimization}

Microsoft Excel ${ }^{\mathrm{TM}}$ enables the use of the Solver tool, in which the user defines the objective, variable cells, and constraints. In this case, the planting area and maximum fish stocking density were selected as variable cells, respectively constrained between 500 and $5000 \mathrm{~m}^{2}$, and 30 and $60 \mathrm{~kg} \mathrm{~m}^{-3}$. Maximizing the sum of NUE P and WUE was used as the objective for the Solver tool. NUE $\mathrm{N}$ is not regarded, as $\mathrm{N}$ can be considered a non-exhaustive renewable resource. Also, the use of $\mathrm{P}$ supplements in the HPS was constrained to zero. If no feasible solution could be found, the solution with the lowest amount of P supplement was selected.

\section{Sensitivity analysis}

By performing a sensitivity analysis, the variation of model outputs due to variation in model inputs and parameters values was investigated. Parameters involved in the sensitivity analysis are fish metabolism parameters regarding $\mathrm{N}$ and $\mathrm{P}, \mathrm{N}$ and $\mathrm{P}$ mineralization rates in the anaerobic digester, protein content of fish feed, $\mathrm{P}$ content of fish feed, air relative humidity $(\mathrm{RH})$, and air temperature. A local sensitivity analysis was performed to quantify the impact of these parameters on the KPIs. The following equation was used to compute the so-called normalized sensitivity (Tomovic 1963):

$$
S_{y}=\frac{\delta y}{\delta x} \cdot \frac{\bar{x}}{\bar{y}},
$$

in which $y$ is a specific model output and $x$ is a specific model input parameter. The overbar indicates nominal values; thus, multiplication by $\frac{\bar{x}}{\bar{y}}$ normalizes the sensitivity value. 


\section{Results}

A 50-day pattern and 365-day pattern are present in the concentrations of $\mathrm{N}$ and $\mathrm{P}$ in the RAS, and can respectively be seen in Fig. 3 (emphasized by ellipses) and Fig. 4 (see dashed lines). In Figs. 3 and 4, there is a clear trend of decreasing concentrations of $\mathrm{N}$ and $\mathrm{P}$ in the RAS at the time evapotranspiration increases, e.g., around day 250 , as a result of increased uptake by the plants. In Figs. 3 and 4, it is apparent that the concentration of $\mathrm{N}$ and $\mathrm{P}$ in the nutrient solution (solid lines) is at their respective threshold for the first 150 200 days. Notice from Fig. 3 that the concentration of $\mathrm{N}$ in the nutrient solution starts increasing at a steady rate starting around day 175, but stops increasing and starts decreasing at a steady rate around day 350. An interesting aspect of Figs. 3 and 4 is that the concentration of $\mathrm{N}$ in the RAS is higher than the concentration of $\mathrm{N}$ in the nutrient solution, but the concentration of $\mathrm{P}$ in the RAS is lower than the concentration of $\mathrm{P}$ in the nutrient solution.

For additional model output and accompanying interpretation, the reader is referred to Appendix E.

Notice from Table 5 that efficient use of both nutrients and water is not achieved in the nominal situation. It is apparent that the biogas yield is not sufficient to power the system, and the collection of solar radiation energy is a necessity to achieve self-sufficiency.

The system design optimization resulted in a system that differs from the nominal system design. For the optimal system design, the planting area has been increased to $2627 \mathrm{~m}^{2}$, with the design parameters of the RAS remaining the same as in the nominal situation. It is apparent from Table 5 that the optimized design results in a system with a significantly higher nutrient and water use efficiency.

Results of the sensitivity analysis show that the P feed content and the P mobilization rate are the only parameters that have a significant impact on model outputs. The reader is referred to Appendix D for the detailed results of the sensitivity analysis.

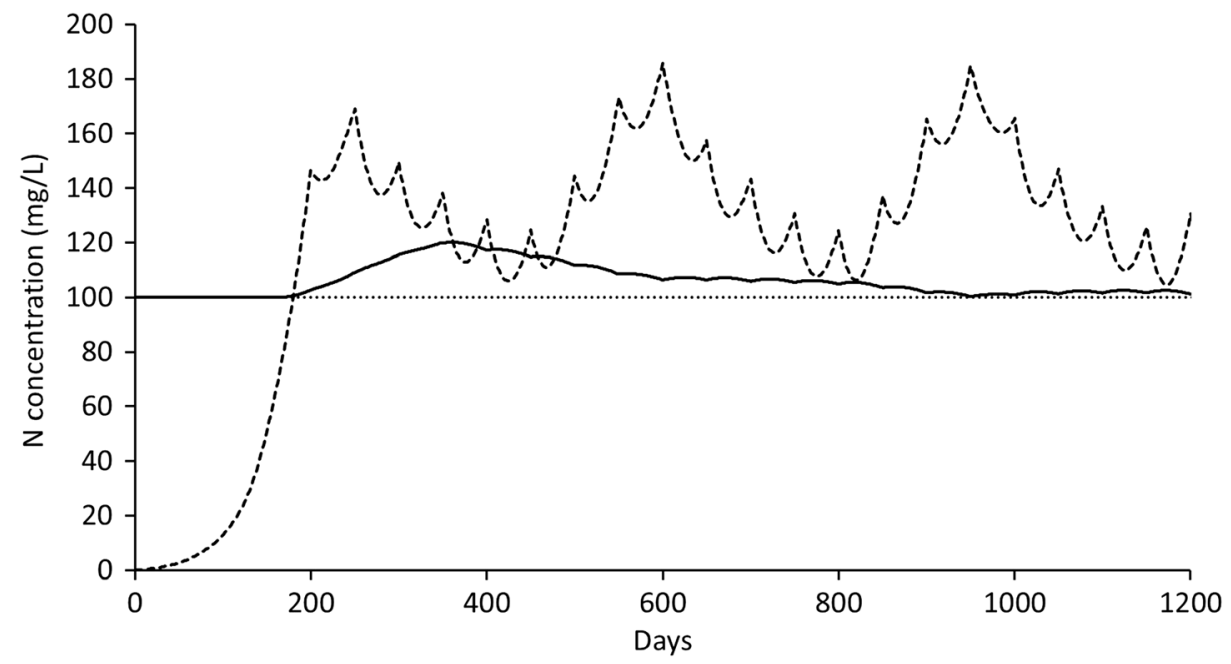

Fig. 3 Nitrate-nitrogen concentration in RAS water (dashed line), nitrogen concentration in the nutrient solution (solid line), and concentration threshold (dotted line) 


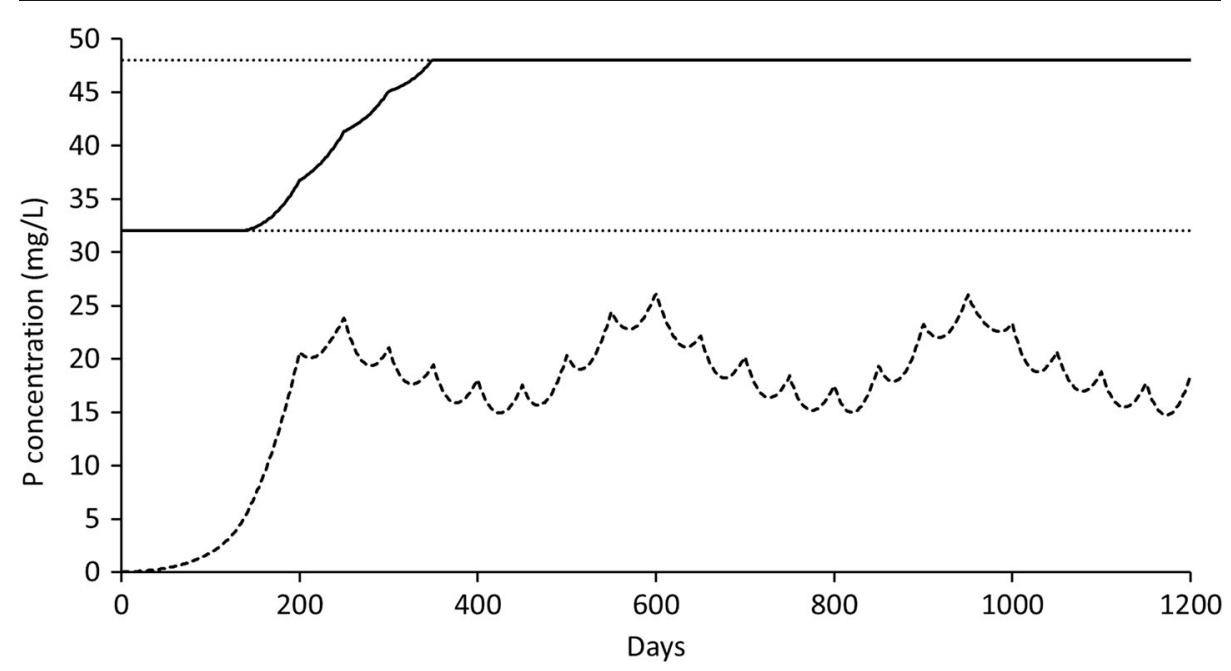

Fig. 4 Phosphorus concentration in RAS water (dashed line), in the nutrient solution (solid line), and required concentration threshold and upper limit (dotted line) for phosphorus in the nutrient solution

\section{Discussion}

The current study found that a 50-day pattern and 365-day pattern are present in the concentrations of N and P in the RAS (Figs. 3 and 4). Due to the method of staggered fish production, the amount of fish biomass reaches a peak every 50 days. Feed input, and thus nutrient input, is dependent on fish biomass in the system, meaning that nutrient input follows the same pattern. This pattern is a determining factor in the dynamics of our system and is the cause of the 50-day pattern that can be seen in the concentrations of nutrients in the RAS and the nutrient solution. Since evapotranspiration is computed using climate data, a 365-day pattern was found, as can be seen in Fig. 2. When the evapotranspiration rate is at its maximum, most water will flow from the RAS to the HPS to keep the total volume of the nutrient solution constant. Therefore, nutrient concentrations in RAS water will decrease. Both for $\mathrm{N}$ and $\mathrm{P}$, it is visible that supplementing of nutrients is necessary during the starting phase of the system. Supplementing of nutrients during the starting phase can be avoided if the

Table 5 Key performance indicators and other relevant model outputs of the system in the nominal situation and the optimal situation

\begin{tabular}{llll}
\hline Parameter & Nominal situation & Optimal situation & Unit \\
\hline NUE N & 65.97 & 77.74 & $\%$ \\
NUE P & 77.00 & 95.09 & $\%$ \\
WUE & 65.23 & 99.74 & $\%$ \\
Feeding rate ratio & 9.08 & 5.19 & $\mathrm{~g} \mathrm{~m}^{-2} \mathrm{day}^{-1}$ \\
Solar collector surface required & 6.7 & 11.7 & $\mathrm{~m}^{2}$ \\
PV panel surface requirement & 78.1 & 78.2 & $\mathrm{~m}^{2}$ \\
N in feed & 763 & 763 & $\mathrm{~kg}^{2}$ \\
P in feed & 204 & 204 & $\mathrm{~kg}$ \\
N supplemented & 0.151 & 10.424 & $\mathrm{~kg}$ \\
P supplemented & 0.0 & 0.0 & $\mathrm{~kg}$ \\
\hline
\end{tabular}


coupling between RAS and HPS takes place after $\mathrm{N}$ and $\mathrm{P}$ concentrations reach the required level. However, this last option may not be considered as economically feasible. Thus, after $\mathrm{N}$ and $\mathrm{P}$ concentrations in the RAS reach a certain level, the inflow of nutrients into the nutrient solution of the HPS is sufficient, and no supplements are required. $\mathrm{N}$ concentration in the nutrient solution starts to decrease around day 350 because $\mathrm{P}$ reaches its concentration limit on day 350, meaning that dilution of the nutrient solution is needed. $\mathrm{P}$ concentration in the nutrient solution is higher than in RAS water due to the fact that almost all P present in solid excretion will flow into the nutrient solution via the anaerobic digester. Because the mobilization rate of $\mathrm{N}$ is significantly lower than the mobilization rate of $\mathrm{P}$, and because significantly more $\mathrm{N}$ is excreted in soluble form than $\mathrm{P}$ is excreted in soluble form, the concentration of $\mathrm{N}$ in the RAS is higher than the concentration of $\mathrm{N}$ in the nutrient solution.

The NUE of $\mathrm{P}$ is higher than the NUE of $\mathrm{N}$ due to the significantly higher mobilization rate of $\mathrm{P}$ in the anaerobic digester. Efficient use of nutrients and water is not achieved in the nominal situation because not enough nutrients are taken up by the plants, allowing the $\mathrm{P}$ concentration to reach its limit. During the dilution that consequently is required, nutrients and water are wasted.

Because the planting area is almost twice as large in the optimal situation as for the nominal situation, $\mathrm{P}$ concentration in the nutrient solution does not reach its limit. Therefore, no dilution of the nutrient solution is required, meaning there is no loss of nutrients and water. However, the concentration of $\mathrm{N}$ in the nutrient solution is only sufficient during the months that the evapotranspiration rate is high and nutrient transfer from the RAS to the HPS is high. During the months with a low evapotranspiration rate, supplementing of $\mathrm{N}$ is required, explaining the increased amount of $\mathrm{N}$ supplement compared with the nominal situation.

$\mathrm{P}$ feed content and $\mathrm{P}$ mobilization rate were the only parameters which have a significant impact on the pre-specified model outputs (see Table 14 and Table 15). This effect can be explained by the fact that the $\mathrm{P}$ concentration range is small, easily leading to a dilution requirement of the nutrient solution. At a low $\mathrm{P}$ mobilization rate, WUE is high, but the NUE of $\mathrm{P}$ is low. In this case, the dilution requirement is low because the inflow of $\mathrm{P}$ into the nutrient solution from the anaerobic digester is low. However, relatively large amounts of $\mathrm{P}$ are lost in the waste sludge of the digester. Furthermore, constant supplementation of $\mathrm{P}$ into the nutrient solution is necessary to meet the $\mathrm{P}$ concentration requirement. The variation in the model outputs caused by a variation in P mobilization rate is small compared with the variation in model outputs caused by variation in feed contents. WUE is most sensitive to P mobilization rate, which can be explained by the fact that high $\mathrm{P}$ mobilization rates lead to dilution of the nutrient solution.

In the nominal situation, the feeding rate ratio of our multi-loop DAPS is $9.08 \mathrm{~g} \mathrm{day}^{-1} \mathrm{~m}^{-2}$. Rakocy et al. (2004) showed that for the production of basil and tilapia in a conventional coupled aquaponic system, a feeding rate ratio of $99.6 \mathrm{~g} \mathrm{day}^{-1} \mathrm{~m}^{2}$ is required. This system was a single-loop system without a digester. Lennard (2012) suggests a much lower feeding rate ratio of $16 \mathrm{~g} \mathrm{day}^{-1} \mathrm{~m}^{2}$ for an aquaponic system where tilapia and lettuce are combined, and adds that a higher crop density is possible, leading to an even lower feeding rate ratio. Endut et al. (2010) suggest an optimal feeding rate ratio of $15-42 \mathrm{~g} \mathrm{day}^{-1} \mathrm{~m}^{-2}$ in an aquaponic system with African catfish (Clarias gariepinus) and spinach. The feeding rate ratio in our system is much lower, which can be explained by the difference in climate and system design (Goddek and Körner 2019). Goddek and Körner (2019) also showed that under controlled environmental conditions and the implementation of a distillation unit (Goddek and Keesman 2018), both 
dilution of hydroponics water and/or bleed-off of aquaculture water might not even be necessary.

The multi-loop DAPS has a digester, resulting in nutrient mobilization which makes fish feed more efficient as a nutrient supplier for the plants. Notice that only $\mathrm{N}$ and $\mathrm{P}$ were regarded in this model; other nutrients required by plants might be in shortage in the current situation.

Nutrient concentration ranges of the nutrient solution have a significant impact on the behavior and optimal design of an AP system because these ranges determine when dilution of the nutrient solution or supplementing of the nutrient solution occurs. Dilution of the nutrient solution is undesirable since water and nutrients are wasted. Supplementing is less undesirable, but undermines the self-sufficiency of the AP system. For the case considered in this study, P concentration in the nutrient solution is in many cases a determining factor. Since the concentration range is smaller than the concentration range of $\mathrm{N}$, there is a higher chance for a dilution or supplementation requirement when the ranges are not met. Different pieces of advice for nutrient concentration requirements for a hydroponic nutrient solution are found in literature. These different advices suggest that nutrient concentration requirements are not as strict as they are presented to be in this research study. Furthermore, when nutrient concentrations do not meet their requirements, it does not mean that there is no yield. When setting the nutrient concentration ranges, one should know whether the aim is to achieve optimal or acceptable nutrient concentrations. With optimal nutrient concentrations, plant growth is optimal. With acceptable nutrient concentrations, plant growth will not be optimal, but no nutrient deficiencies will occur either.

A planting area size increase of $75 \%$ in the existing Kikaboni farm leads to an optimal system design. Dilution of the nutrient solution does not occur in this situation, meaning that nutrients and water are only lost in the waste sludge of the digester. In reality, increasing the total planting area might not be an option, especially when the system is in an urban area. Also, some flexibility in system size may be needed to account for uncertainty in the inputs and parameters used.

\section{Conclusion}

The findings of this model-based design study clearly indicate that the guidelines for designing an aquaponic system, as found in literature, do not necessarily lead to an optimal system design of a multi-loop DAPS. The main reason for this deviation is the presence of a digester in a multi-loop DAPS. Furthermore, nutrient concentration ranges have a large impact on the performance of any aquaponic system, in terms of sustainability, since these ranges determine when dilution or supplementing of the nutrient solution is needed. The model-based design, as presented in this paper, proved to be helpful in finding sustainable system designs of a multiloop DAPS.

\section{Compliance with ethical standards}

Conflict of interest The authors declare that they have no conflict of interest.. 


\section{Appendices}

\section{Appendix A. Parametrization FAO Penman-Monteith equation}

Table 6 Greenhouse properties of Kikaboni farm, used in the computation of reference evapotranspiration $\left(E T_{0}\right)$ using the FAO-Penman Monteith equation

\begin{tabular}{lcl}
\hline Parameter & Value & Unit \\
\hline Wind speed & 0.018 & $\mathrm{~m} \mathrm{~s}^{-1}$ \\
Greenhouse glazing transmittance & 75 & $\%$ \\
Shading factor & 25 & $\%$ \\
Canopy reflection coefficient & 0.23 & - \\
Altitude & 1800 & $\mathrm{~m}$ \\
Latitude & -1 & $\circ$ \\
Minutes & 47 & $\cdot$ \\
\hline
\end{tabular}

Table 7 Weather data for the Kikaboni farm, compiled from weather data of 8 years (2009-2016)

\begin{tabular}{llllllll}
\hline & Max temperature $^{1}$ & Min temperature & $\mathrm{RH}_{\max }{ }^{1}$ & $\mathrm{RH}_{\min }{ }^{1}$ & $\mathrm{RH}^{1}$ & Solar radiation $\left(R_{S}\right)^{2}$ & $E T_{0}$ \\
\hline & ${ }^{\circ} \mathrm{C}$ & ${ }^{\circ} \mathrm{C}$ & $\%$ & $\%$ & $\%$ & $\mathrm{MJ} / \mathrm{m} 2 /$ day & $\mathrm{mm} /$ day \\
January & 26.3 & 13.0 & 81.1 & 61.1 & 71.1 & 25.64 & 2.46 \\
February & 27.8 & 14.1 & 76.3 & 56.3 & 66.3 & 25.75 & 2.54 \\
March & 27.5 & 15.0 & 78.9 & 58.9 & 68.9 & 25.32 & 2.56 \\
April & 25.3 & 15.9 & 92.0 & 72.0 & 82.0 & 20.3 & 1.14 \\
May & 23.9 & 14.8 & 95.5 & 75.5 & 85.5 & 18.29 & 1.57 \\
June & 23.4 & 13.9 & 92.1 & 72.1 & 82.1 & 15.53 & 1.55 \\
July & 23.8 & 12.9 & 85.6 & 65.6 & 75.6 & 15.71 & 2.59 \\
August & 24.1 & 13.9 & 82.6 & 62.6 & 72.6 & 15.66 & 2.09 \\
September & 26.0 & 14.8 & 78.4 & 58.4 & 68.4 & 20.72 & 2.19 \\
October & 26.3 & 15.6 & 79.6 & 59.6 & 69.6 & 21.24 & 2.42 \\
November & 24.9 & 15.1 & 89.3 & 69.3 & 79.3 & 21.46 & \\
December & 25.0 & 13.6 & 89.4 & 69.4 & 79.4 & 24.78 & \\
\hline
\end{tabular}

${ }^{1}$ Derived from worldweatheronline.com

${ }^{2}$ Onyango and Ongoma (2015)

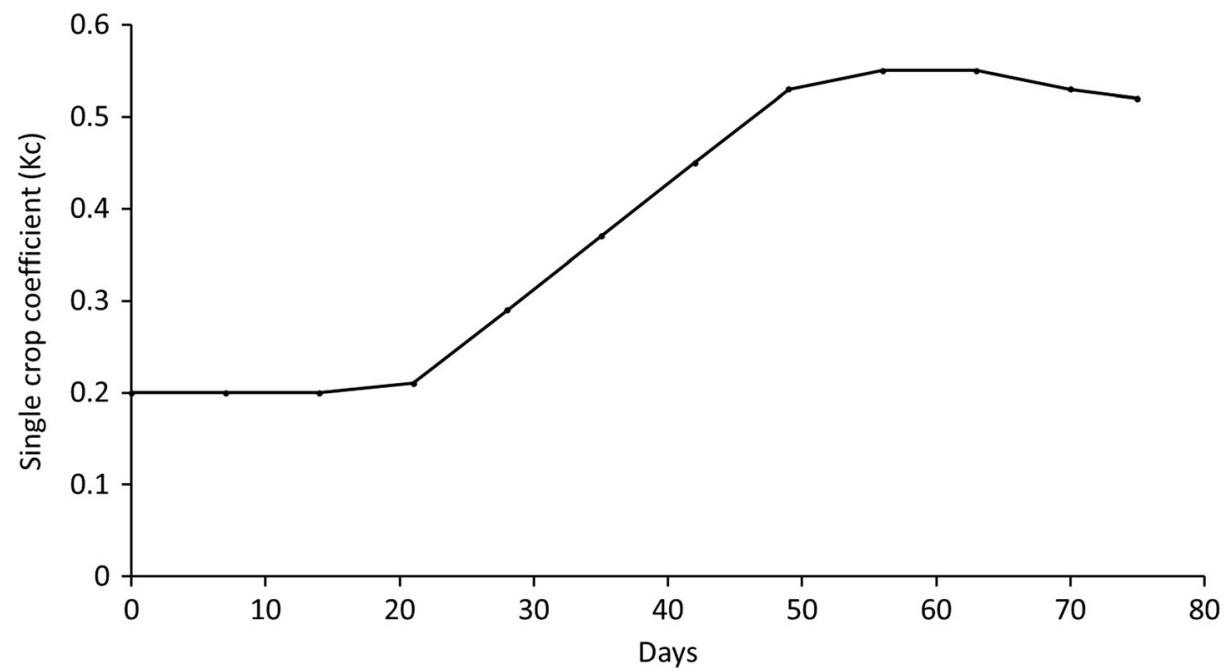

Fig. 5 Crop coefficient $\left(K_{c}\right)$ curve for lettuce (Allen et al. 1998). 


\section{Appendix B. Water, mass, and energy balances}

In what follows, the basic principles of conservation of mass and energy are applied to our AP system, and which in words can be summarized as storage = inflow - outflow + production. Consequently, the dynamic behavior of our AP system, thus where the storage term is not neglected, is described in terms of differential equations. The structure of the Appendix is such that first a balance is introduced, followed by detailed expressions for each of the terms, and then the next balance, and so on.

\section{Water balance}

A volume balance for water of the entire system is relevant since it determines the flow of nutrients and provides insight on water use:

$$
\frac{d V^{\text {water }}}{d t}=Q_{g w}-Q_{E T}-\alpha \cdot Q_{S W}-Q_{d l}^{H P S}
$$

in which $V^{\text {water }}$ is the total volume of water in the system, $Q_{g w}$ is the volumetric flow rate of inflowing groundwater in the AP system, $Q_{E T}$ the volumetric flow rate of evapotranspiration water, $Q_{S W}$ the volumetric flow rate of fish sludge, and $Q_{d l}^{H P S}$ the volumetric flow rate of water removed during dilution of the nutrient solution. Parameter $\alpha$ represents the fraction of fish sludge that ends up in the waste sludge (Fig. 1), thus leaving the system.

From the fact that the water level in the AP system is constant can be derived that

$$
\frac{d V^{\text {water }}}{d t}=0
$$

$Q_{E T}$ is computed using the FAO-Penmann Monteith equation (Allen et al. 1998).

The volumetric flow rate of fish sludge at time $t$ is defined as

$$
Q_{S W}(t)=\frac{\dot{m}_{\text {feed }}(t) \cdot c_{\text {feed }}^{D M} \cdot \beta \cdot \frac{1-w_{\text {sludge }}^{T S}}{w_{\text {sludge }}^{T S}}}{\rho_{\text {water }}}
$$

in which $\dot{m}_{\text {feed }}(t)$ is the mass flow rate of feed at time $t, c_{\text {feed }}^{D M}$ is the mass fraction of dry matter in feed, $\beta$ is the mass fraction of feed (dry matter) that ends up in the RAS water as solids, of which the value can be found in Table $1, w_{\text {sludge }}^{T S}$ is the mass fraction of solids in fish sludge, and $\rho_{\text {water }}$ is the density of the fish water. The term $\dot{m}_{\text {feed }}(t) \cdot c_{\text {feed }}^{D M} \cdot \beta$ equals the mass of the solids that are in the sludge stream, which is multiplied by the term $\frac{1-w_{\text {sludge }}^{T S}}{w_{\text {sludge }}^{T S}}$ to find the mass of the liquid part of the sludge stream.

The computation of dilution of the nutrient solution is defined as

$$
V_{d l}^{H P S}(t)=\max _{x} \frac{m_{\mathrm{HPS}}^{x}(t)-c_{\mathrm{HPSmax}}^{x} \cdot V_{\mathrm{HPS}}}{c^{x}(t)-c_{g w}^{x}} \text { where } x \in\{N, P\} \text {, if } c(t)>c_{\max }^{x}
$$

in which $V_{d l}^{\mathrm{HPS}}(t)$ is the replacement volume at time $t, m_{\mathrm{HPS}}^{x}(t)$ the mass of nutrient $x$ in the nutrient solution at time $t, c_{\mathrm{HPS} \text { max }}^{x}$ the maximum mass concentration of nutrient $x$ in the nutrient solution, $V_{H P S}$ the total volume of the nutrient solution, $c^{x}(t)$ the mass concentration of 
nutrient $x$ in the nutrient solution at time $t$, and $c_{g w}^{x}$ the mass concentration of compound $x$ in groundwater.

The volume balance of water for the RAS is defined as

$$
\frac{d V_{\mathrm{RAS}}^{\mathrm{water}}}{d t}=Q_{g w}^{R A S}-Q_{S W}-Q_{d l}^{\mathrm{RAS}}-Q_{\mathrm{refill}}^{\mathrm{HPS}}
$$

in which $V_{\mathrm{RAS}}^{\mathrm{water}}$ is the total volume of water in the RAS, $Q_{g w}^{\mathrm{RAS}}$ is the volumetric flow rate of groundwater flowing into the RAS, $Q_{d l}^{\mathrm{RAS}}$ the volumetric flow rate of water flowing out of the RAS to the HPS when RAS water is diluted, and $Q_{\text {refill }}^{\text {HPS }}$ the volumetric flow rate of water flowing from the RAS to the HPS to keep the water level in the HPS constant.

From the fact that the water level in the RAS is constant can be derived that

$$
\frac{d V_{\mathrm{RAS}}^{\mathrm{water}}}{d t}=0
$$

The required water replacement volume in the RAS at time $t$ is defined as

$$
V_{d l}^{\mathrm{RAS}}(t)=\max _{x} \frac{m_{\mathrm{RAS}}^{x}(t)-c_{\mathrm{RASmax}}^{x} \cdot V_{\mathrm{HPS}}}{c_{R A S}^{x}(t)-c_{g w}^{x}} \text { where } x \in\left\{N H_{3}-N, N O_{3}-N\right\}
$$

in which $V_{d l}^{\mathrm{RAS}}(t)$ is the replacement volume at time $t, m_{\mathrm{RAS}}^{x}(t)$ the mass of compound $x$ in the RAS water at time $t, c_{\text {RASmax }}^{x}$ the maximum allowed mass concentration of compound $x$ in the RAS water, $c_{\mathrm{RAS}}^{x}(t)$ the mass concentration of compound $x$ in the RAS water at time $t$.

The water volume balance of the HPS is defined as

$$
\frac{d V_{\mathrm{HPS}}^{\mathrm{water}}}{d t}=Q_{\mathrm{refill}}^{\mathrm{HPS}}+Q_{g w}^{\mathrm{HPS}}+Q_{d l}^{\mathrm{RAS}}+Q_{\mathrm{ANA}}-Q_{\mathrm{ET}}-Q_{d l}^{\mathrm{HPS}}
$$

in which $V_{\mathrm{HPS}}^{\mathrm{water}}$ is the total volume of the nutrient solution, $Q_{g w}^{\mathrm{HPS}}$ is the volumetric flow rate of groundwater into the nutrient solution, being equal to the volumetric flow rate $Q_{d l}^{\mathrm{HPS}}$ out of the nutrient solution during dilution, and $Q_{\mathrm{ANA}}$ the volumetric flow rate of effluent from the anaerobic digester into the nutrient solution. From the fact that the water level in the HPS is constant can be derived that

$$
\frac{d V_{\mathrm{HPS}}^{\mathrm{water}}}{d t}=0
$$

$Q_{\mathrm{ANA}}$ is defined as

$$
Q_{\mathrm{ANA}}(t)=\gamma \cdot Q_{\mathrm{SW}}(t)
$$

in which $\gamma$ is the fraction of fish sludge that is present in the effluent.

\section{Nitrogen, phosphorus, and COD mass balances}

In the RAS, $\mathrm{N}$ flows into the system as feed but is divided into $\mathrm{NO}_{3}-\mathrm{N}$ and TAN due to fish metabolism. 
The mass balance for $\mathrm{NO}_{3}-\mathrm{N}$ in the RAS is defined as

$$
\frac{d m_{\mathrm{RAS}}^{\mathrm{NO}_{3}-\mathrm{N}}}{d t}=p^{\mathrm{TAN}} \cdot \eta_{b f}+Q_{g w}^{\mathrm{RAS}} \cdot\left(c_{g w}^{\mathrm{NO}_{3}-\mathrm{N}}+\eta \cdot c_{g w}^{\mathrm{TAN}}\right)-\left(Q_{\mathrm{SW}}+Q_{d l}^{\mathrm{RAS}}+Q_{\mathrm{refill}}^{\mathrm{HPS}}\right) \cdot c_{\mathrm{RAS}}^{\mathrm{N}-\mathrm{NO}_{3}}(15)
$$

in which $m_{\mathrm{RAS}}^{\mathrm{NO}_{3}-\mathrm{N}}$ is the mass of $\mathrm{NO}_{3}-\mathrm{N}$ in the RAS water, $p^{\mathrm{TAN}}$ the production of TAN by fish, $c_{g w}^{\mathrm{NO}_{3}-\mathrm{N}}$ the mass concentration of $\mathrm{NO}_{3}-\mathrm{N}$ in groundwater, and $\mathrm{c}_{\mathrm{RAS}}^{\mathrm{NO}_{3}-\mathrm{N}}$ the mass concentration of $\mathrm{NO}_{3}-\mathrm{N}$ in the RAS water. Parameter $\eta_{b f}$ represents the efficiency of the biofilter, thus the percentage of TAN that is nitrified.

Fish production of TAN is defined as:

$$
p^{\mathrm{TAN}}(t)=\dot{m}_{\text {feed }}(t) \cdot w_{\text {feed }}^{\mathrm{N}} \cdot \delta \cdot \epsilon
$$

in which $w_{\text {feed }}^{\mathrm{N}}$ is the mass fraction of $\mathrm{N}$ in fish feed, $\delta$ is the fraction of feed ingested by fish, and $\epsilon$ the fraction of $\mathrm{N}$ eaten by the fish that is excreted as TAN.

The mass balance for TAN in the RAS is defined as

$$
\frac{d m_{\mathrm{RAS}}^{\mathrm{TAN}}}{d t}=p^{\mathrm{TAN}} \cdot\left(1-\eta_{b f}\right)+Q_{g w}^{\mathrm{RAS}} \cdot c_{g w}^{\mathrm{TAN}} \cdot\left(1-\eta_{b f}\right)-\left(Q_{\mathrm{SW}}+Q_{d l}^{\mathrm{RAS}}+Q_{\mathrm{refill}}^{\mathrm{HPS}}\right) \cdot c_{\mathrm{RAS}}^{\mathrm{TAN}}
$$

in which $m_{\mathrm{RAS}}^{\mathrm{TAN}}$ is the mass of TAN in the RAS water, $c_{g w}^{\mathrm{TAN}}$ the mass concentration of TAN in groundwater, and $c_{\mathrm{RAS}}^{\mathrm{TAN}}$ the mass concentration of TAN in the RAS water.

The mass balance for $\mathrm{P}$ in the RAS is as follows:

$$
\frac{d m_{\mathrm{RAS}}^{\mathrm{P}}}{d t}=\dot{m}_{\text {feed }}(t) \cdot w_{\text {feed }}^{\mathrm{P}} \cdot(1-\zeta)+Q_{g w}^{\mathrm{RAS}} \cdot c_{g w}^{\mathrm{P}}-\left(Q_{S W}+Q_{d l}^{\mathrm{RAS}}+Q_{\mathrm{refill}}^{\mathrm{HPS}}\right) \cdot c_{\mathrm{RAS}}^{\mathrm{P}}
$$

in which $m_{\mathrm{RAS}}^{\mathrm{P}}$ is the mass of $\mathrm{P}$ in the RAS water, $w_{\text {feed }}^{\mathrm{P}}$ is the mass fraction of $\mathrm{P}$ in feed, $\zeta$ is the mass fraction of ingested $\mathrm{P}$ retained by fish, $c_{g w}^{\mathrm{P}}$ is the mass concentration of $\mathrm{P}$ in groundwater, and $c_{\mathrm{RAS}}^{\mathrm{P}}$ is the mass concentration of $\mathrm{P}$ in RAS water.

In the HPS, total $\mathrm{N}$ is regarded instead of nitrate-nitrogen and TAN. The mass balance of $\mathrm{N}$ in the HPS is defined as

$$
\begin{aligned}
\frac{d m_{\mathrm{HPS}}^{\mathrm{N}}}{d t}= & \left(Q_{d l}^{\mathrm{RAS}}+Q_{\mathrm{refill}}^{\mathrm{HPS}}\right) \cdot\left(c_{\mathrm{RAS}}^{\mathrm{NO}_{3}-\mathrm{N}}+c_{\mathrm{RAS}}^{\mathrm{TAN}}\right)+Q_{\mathrm{ANA}} \cdot c_{\mathrm{ANA}}^{\mathrm{N}}+Q_{d l}^{\mathrm{HPS}} \\
& \cdot\left(c_{g w}^{\mathrm{NO}_{3}-\mathrm{N}}+c_{g w}^{\mathrm{TAN}}\right)+\dot{m}_{\mathrm{supp}}^{\mathrm{N}}-\left(Q_{d l}^{\mathrm{HPS}}+Q_{\mathrm{ET}}\right) \cdot c_{\mathrm{HPS}}^{\mathrm{N}}
\end{aligned}
$$

in which $m_{\mathrm{HPS}}^{\mathrm{N}}$ is the mass of $\mathrm{N}$ in the nutrient solution, $c_{\mathrm{ANA}}^{\mathrm{N}}$ is the mass concentration of $\mathrm{N}$ in the effluent of the anaerobic digester, $\dot{m}_{\text {supp }}^{\mathrm{N}}$ is the mass flow rate of $\mathrm{N}$ supplement into the nutrient solution, and $c_{\mathrm{HPS}}^{\mathrm{N}}$ is the mass concentration of $\mathrm{N}$ in the nutrient solution.

The mass flow rate of nutrient $x$ supplement at time $t$ is defined as

$$
\dot{m}_{\text {supp }}^{x}(t)=\frac{V_{\mathrm{HPS}} \cdot c_{\mathrm{HPS} m i n}^{x}-m_{\mathrm{HPS}}^{x}(t)}{T} \text { where } x \in\{N, P\}, \text { if } c_{\mathrm{HP}}^{x}<c_{\mathrm{HPmin}}^{x}
$$

in which $\dot{m}_{\text {supp }}^{x}(t)$ is the mass flow rate of nutrient $x$ supplement flowing into the nutrient solution at time $t, c_{\mathrm{HPSmin}}^{x}$ the minimum required mass concentration of nutrient $x$ in the 
nutrient solution, $m_{\mathrm{HPS}}^{x}(t)$ the mass of nutrient $x$ in the nutrient solution at time $t$, and $T$ the time period during which the supplement is added to the nutrient solution.

$c_{\text {ANA }}^{\mathrm{N}}(t)$ can be computed using

$$
c_{\mathrm{ANA}}^{\mathrm{N}}(t)=\frac{\left(\left(\dot{m}_{\mathrm{feed}}(t) \cdot c_{\mathrm{feed}}^{\mathrm{N}}\right) \cdot(1-\delta+\xi \cdot \delta)+Q_{S W}(t) \cdot\left(c_{\mathrm{RAS}}^{\mathrm{NO}_{3}-\mathrm{N}}(t)+c_{\mathrm{RAS}}^{\mathrm{TAN}}(t)\right)\right) \cdot \iota}{Q_{\mathrm{ANA}}(t)}
$$

in which $\xi$ is the fraction of ingested $\mathrm{N}$ that is excreted as feces, and $\iota$ is the fraction of $\mathrm{N}$ flowing into the digester that is present in the effluent.

The mass balance of $\mathrm{P}$ in the HPS is as follows:

$$
\begin{aligned}
\frac{d m_{\mathrm{HPS}}^{\mathrm{P}}}{d t}= & \left.\left(Q_{d l}^{\mathrm{RAS}}+Q_{\mathrm{refill}}^{\mathrm{HPS}}\right) \cdot\left(c_{\mathrm{RAS}}^{\mathrm{P}}\right)+Q_{\mathrm{ANA}} \cdot c_{\mathrm{ANA}}^{\mathrm{P}}+Q_{d l}^{\mathrm{HPS}} \cdot c_{g w}^{\mathrm{P}}\right) \\
& +\dot{m}_{\mathrm{supp}}^{\mathrm{P}}-\left(Q_{d l}^{\mathrm{HPS}}+Q_{\mathrm{ET}}\right) \cdot c_{\mathrm{HPS}}^{\mathrm{P}}
\end{aligned}
$$

in which $m_{\mathrm{HPS}}^{\mathrm{P}}$ is the mass of $\mathrm{P}$ in the nutrient solution, $c_{\mathrm{ANA}}^{\mathrm{P}}$ is the concentration of $\mathrm{P}$ in the effluent of the anaerobic digester, $\dot{m}_{\text {supp }}^{\mathrm{P}}$ the mass flow rate of $\mathrm{P}$ fertilizer into the nutrient solution, and $c_{\mathrm{HPS}}^{\mathrm{P}}$ the concentration of $\mathrm{P}$ in the nutrient solution.

A mass balance for COD present in the RAS is relevant since it is required to determine the amount of COD flowing to the anaerobic digester:

$$
\frac{d m_{\mathrm{RAS}}^{\mathrm{COD}}}{d t}=Q_{g w}^{\mathrm{RAS}} \cdot c_{g w}^{\mathrm{COD}}+\dot{m}_{\mathrm{feed}} \cdot w_{\text {feed }}^{\mathrm{COD}} \cdot(1-\delta \cdot \kappa)-\left(Q_{S W}+Q_{d l}^{\mathrm{RAS}}+Q_{\mathrm{refill}}^{\mathrm{HPS}}\right) \cdot c_{\mathrm{RAS}}^{\mathrm{COD}}
$$

in which $m_{\mathrm{RAS}}^{\mathrm{COD}}$ is the mass of COD in the RAS water, $c_{g w}^{\mathrm{COD}}$ the concentration of COD in groundwater, $w_{\text {feed }}^{\mathrm{COD}}$ the mass fraction of COD in feed, $\kappa$ the fraction of ingested COD retained by the fish, and $c_{\mathrm{RAS}}^{\mathrm{COD}}$ the concentration of COD in the RAS water. From this equation, the flow of COD to the digester $\dot{m}_{\text {dig }}^{\text {COD }}$ can be derived:

$$
\dot{m}_{\text {dig }}^{\mathrm{COD}}(t)=\dot{m}_{\text {feed }}(t) \cdot w_{\text {feed }}^{\mathrm{COD}} \cdot((1-\delta)+\delta \cdot \lambda)+Q_{S W}(t) \cdot c_{\mathrm{RAS}}^{\mathrm{COD}}(t)
$$

in which $\lambda$ is the fraction of ingested COD that is excreted as feces.

\section{Energy balance}

Methane produced in the anaerobic digester will be converted into energy using a generator. Energy is consumed by two identical pumps and a blower in the biofilter. The pumps and the blower are running constantly at a constant consumption level. From this information, the energy balance is given by:

$$
\frac{d E}{d t}=p_{\text {gen }}^{E}+p_{\text {sol }}^{E}+p_{P V}^{E}-2 \cdot P_{\text {pump }}-P_{\text {blower }}-Q_{g w}^{E}
$$

in which $p_{\text {gen }}^{E}$ is the production of electric energy by the generator, $p_{\text {sol }}^{E}$ the production of solar thermal energy, $p_{P V}^{E}$ the production of solar electric energy, $P_{\text {pump }}^{E}$ the power of the pump, $P_{\text {blower }}^{E}$ the amount of energy used by the blower, and $Q_{g w}^{E}$ the rate of heat flow to the inflowing groundwater in the RAS. 
Since the system is supposed to be self-sufficient, it can be stated that

$$
\frac{d E}{d t}=0
$$

The production of energy by the anaerobic digester is defined as

$$
p_{\mathrm{gen}}^{E}(t)=\dot{m}_{\text {dig }}^{\mathrm{COD}}(t) \cdot \mu \cdot u \cdot \eta_{\text {gen }}
$$

in which $\mu$ is the biogas yield per mass unit of COD, $u$ is the energy density of methane, and $\eta_{g e n}$ is the energy conversion efficiency of the generator.

The production of solar thermal energy can be computed using

$$
p_{\mathrm{sol}}^{E}=\overline{R_{s}} \cdot A_{s p} \cdot \eta_{\mathrm{s} p}
$$

in which $\overline{R_{s}}$ is the average solar radiation computed from data in appendix $\mathrm{A}, A_{s p}$ the total surface of the solar collectors, and $\eta_{s p}$ the thermal efficiency of the solar water heating system.

Electric energy is produced using PV panels, of which the quantity of production is defined as

$$
p_{P V}^{E}=\overline{R_{s}} \cdot A_{P V} \cdot \eta_{P V}
$$

in which $A_{P V}$ is the surface area of the PV-panels, and $\eta_{P V}$ is the efficiency of the PV-panels.

The rate of heat flow to the inflowing groundwater in the RAS is as follows:

$$
Q_{g w}^{E}(t)=Q_{g w}^{R A S}(t) \cdot c_{p} \cdot \rho \cdot\left(\bar{T}-T_{g w}\right)
$$

in which $c_{p}$ is the specific heat of groundwater, and $\rho$ the density of groundwater, $\bar{T}$ is the water temperature in the RAS, and $T_{g w}$ is the temperature of the inflowing groundwater.

Table 8 Coefficients used in the mathematical model

\begin{tabular}{ll}
\hline Parameter & Definition \\
\hline$\alpha$ & Mass fraction of fish sludge that will end up in the waste sludge \\
$\beta$ & Mass fraction of feed (dry matter) that ends up in the RAS water as solids \\
$\gamma$ & Mass fraction of fish sludge that is present in the effluent \\
$\eta_{b f}$ & Efficiency of the biofilter \\
$\delta$ & Mass fraction of feed input ingested by fish \\
$\epsilon$ & Mass fraction of ingested N that is excreted as TAN \\
$\zeta$ & Mass fraction of ingested P retained by fish \\
$\xi$ & Mass fraction of ingested N that is excreted as feces \\
$\iota$ & Mass fraction of N flowing into the digester that is present in the effluent \\
$\kappa$ & Mass fraction of ingested COD retained by the fish \\
$\lambda$ & Mass fraction of ingested COD that is excreted as feces \\
$\mu$ & Biogas yield per mass unit of COD \\
$u$ & Energy density of methane \\
$\eta_{g e n}$ & Energy conversion efficiency of the generator \\
$c$ & Concentration \\
$p$ & Production \\
$Q$ & Volumetric flow rate \\
$m$ & Mass \\
$\dot{m}$ & Mass flow rate \\
\hline
\end{tabular}




\section{Appendix C. Order of calculation steps}

The model was built in Microsoft Excel, in which every row accounts for a day, and every column accounts for one calculation step, as computation of the water and energy balances is performed in a discretized/step-wise manner. The following tables show the order in which these calculation steps are taken. A specific example of the methodology used in this paper, one sheet in Microsoft Excel, is used to compute the water balance of the model. Column A is used to calculate the volumetric flow rate of fish sludge, for which Eq. 7 is used. Column B is used to calculate the volumetric flow rate of effluent of the anaerobic digester, for which Eq. 12 is used, and so on.

Table 9 Order in which calculation steps are taken to numerically solve the water balance differential equations

\begin{tabular}{|c|c|c|c|}
\hline Volumetric flow rate of fish sludge & $Q_{S W}$ & Eq. 7 & $\mathrm{~L}$ \\
\hline Water in waste sludge of anaerobic digester & n.a. & n.a. & $\mathrm{L}$ \\
\hline Required water replacement volume in the RAS & $V_{d l}^{\text {RAS }}$ & Eq. 11 & $\mathrm{~L}$ \\
\hline $\begin{array}{l}\text { Shortage/surplus of water in HPS due to evapotranspiration, effluent water, } \\
\text { and RAS dilution water. }\end{array}$ & n.a. & n.a. & $\mathrm{L}$ \\
\hline Total water in waste streams & n.a. & n.a. & $\mathrm{L}$ \\
\hline Total water input & n.a. & n.a. & $\mathrm{L}$ \\
\hline
\end{tabular}

Table 10 Order in which calculation steps are taken to numerically solve the mass balance differential equations of N, NO3-N, and TAN

\begin{tabular}{|c|c|c|c|}
\hline $\mathrm{N}$ in eaten feed & n.a. & n.a. & $\mathrm{mg}$ \\
\hline $\mathrm{N}$ in uneaten feed & n.a. & n.a. & $\mathrm{mg}$ \\
\hline $\mathrm{N}$ in feces & n.a. & n.a. & $\mathrm{mg}$ \\
\hline $\mathrm{N}$ in solids in the fish tanks & n.a. & n.a. & $\mathrm{mg}$ \\
\hline TAN in RAS & $m$ TAN & n.a. & $\mathrm{mg}$ \\
\hline $\mathrm{NO}_{3}-\mathrm{N}$ in RAS after fish sludge removal and subsequent refilling with groundwater & $m m_{\mathrm{RAS}}^{\mathrm{NO}_{3}-\mathrm{N}}$ & n.a. & $\mathrm{mg}$ \\
\hline TAN in RAS after fish sludge removal and subsequent refilling with groundwater & $m$ RAS & n.a. & $\mathrm{mg}$ \\
\hline $\mathrm{N}$ in the effluent of anaerobic digester & n.a. & n.a. & $\mathrm{mg}$ \\
\hline $\mathrm{NO}_{3}-\mathrm{N}$ in RAS after dilution of RAS water & $m_{\mathrm{RAS}}^{\mathrm{NO}_{3}-\mathrm{N}}$ & n.a. & $\mathrm{mg}$ \\
\hline TAN in RAS after dilution of RAS water & $m$ RAS & n.a. & $\mathrm{mg}$ \\
\hline $\mathrm{N}-\mathrm{NH}_{3}$ in RAS after dilution of RAS water & n.a. & n.a. & $\mathrm{mg}$ \\
\hline $\mathrm{N}$ in HPS after dilution of RAS water & $m_{\mathrm{HPS}}^{\mathrm{N}}$ & n.a. & $\mathrm{mg}$ \\
\hline $\mathrm{N}$ in HPS after removal of $\mathrm{N}$ due to evapotranspiration & $m_{\mathrm{HPS}}^{\mathrm{N}}$ & n.a. & $\mathrm{mg}$ \\
\hline $\mathrm{N}$ in HPS after either removing surplus water or adding RAS water to refill & $m_{\mathrm{HPS}}^{\mathrm{N}}$ & n.a. & $\mathrm{mg}$ \\
\hline $\mathrm{NO}_{3}-\mathrm{N}$ in RAS after HPS refill and subsequent refilling of RAS with groundwater & $m \mathrm{NO}_{3}-\mathrm{N}$ & n.a. & $\mathrm{mg}$ \\
\hline TAN in RAS after HPS refill and subsequent refilling of RAS with groundwater & $m$ RAN & n.a. & $\mathrm{mg}$ \\
\hline Dilution requirement in HPS with regard to $\mathrm{N}$ & n.a. & n.a. & $\mathrm{L}$ \\
\hline TAN in RAS & $m$ RAN & n.a. & $\mathrm{mg} \mathrm{L}^{-1}$ \\
\hline
\end{tabular}


Table 11 Order in which calculation steps are taken to numerically solve the mass balance differential equations of $\mathrm{P}$

\begin{tabular}{|c|c|c|c|}
\hline Calculation step & Symbol & Equation & Unit \\
\hline$P$ in eaten feed & n.a. & n.a. & $\mathrm{mg}$ \\
\hline$P$ in uneaten feed & n.a. & n.a. & $\mathrm{mg}$ \\
\hline$P$ retained by fish & n.a. & n.a. & $\mathrm{mg}$ \\
\hline $\mathrm{P}$ in feces & n.a. & n.a. & $\mathrm{mg}$ \\
\hline Soluble excretion of $\mathrm{P}$ & n.a. & n.a. & $\mathrm{mg}$ \\
\hline $\mathrm{P}$ in solids in the fish tanks & n.a. & n.a. & $\mathrm{mg}$ \\
\hline$P$ in RAS & $m_{\mathrm{RAS}}^{\mathrm{P}}$ & n.a. & $\mathrm{mg}$ \\
\hline $\mathrm{P}$ in RAS after fish sludge removal and subsequent refilling with groundwater & $m_{\mathrm{RAS}}^{\mathrm{P}}$ & n.a. & $\mathrm{mg}$ \\
\hline$P$ in the effluent of the anaerobic digester & n.a. & n.a. & $\mathrm{mg}$ \\
\hline$P$ in waste sludge of anaerobic digester & n.a. & n.a. & $\mathrm{mg}$ \\
\hline$P$ in HPS after the inflow of effluent of the anaerobic digester & $m_{\mathrm{HPS}}^{\mathrm{P}}$ & n.a. & $\mathrm{mg}$ \\
\hline $\mathrm{P}$ in RAS after dilution of RAS water and subsequent refilling with groundwater & $m_{\mathrm{RAS}}^{\mathrm{P}}$ & n.a. & $\mathrm{mg}$ \\
\hline$P$ in HPS after dilution of RAS water & $m_{\mathrm{HPS}}^{\mathrm{P}}$ & n.a. & $\mathrm{mg}$ \\
\hline $\mathrm{P}$ in HPS after removal of $\mathrm{P}$ due to evapotranspiration & $m_{\mathrm{HPS}}^{\mathrm{P}}$ & n.a. & $\mathrm{mg}$ \\
\hline $\mathrm{P}$ in HPS after either removing surplus water or adding RAS water to refill & $m_{\mathrm{HPS}}^{\mathrm{P}}$ & n.a. & $\mathrm{mg}$ \\
\hline$P$ in RAS after HPS refill and subsequent refilling of RAS with groundwater & $m_{\mathrm{RAS}}^{\mathrm{P}}$ & n.a. & $\mathrm{mg}$ \\
\hline Dilution requirement in HPS with regard to $\mathrm{P}$ & n.a. & n.a. & $\mathrm{L}$ \\
\hline P in HPS after bleed off and subsequent refilling of HPS with groundwater & $m_{\mathrm{HPS}}^{\mathrm{P}}$ & n.a. & $\mathrm{mg}$ \\
\hline P removal from HPS due to bleed off & n.a. & n.a. & $\mathrm{mg}$ \\
\hline Required amount of $\mathrm{P}$ supplement & $\dot{m}_{\text {supp }}^{\mathrm{P}}$ & Eq. 20 & $\mathrm{mg}$ \\
\hline P in HPS after supplement & $m_{\mathrm{HPS}}^{\mathrm{P}}$ & n.a. & $\mathrm{mg}$ \\
\hline$P$ in HPS & $m_{\mathrm{HPS}}^{\mathrm{P}}$ & n.a. & $m g \mathrm{~L}^{-1}$ \\
\hline$P$ in RAS & $m_{\mathrm{RAS}}^{\mathrm{P}}$ & n.a. & $\operatorname{mg~L} \mathrm{L}^{-1}$ \\
\hline
\end{tabular}

Table 12 Order in which calculation steps are taken to numerically solve the mass balance differential equation of COD and yield of methane

\begin{tabular}{llll}
\hline Calculation step & Symbol & Equation & Unit \\
\hline COD of eaten feed & & & $\mathrm{kg}$ \\
COD of uneaten feed & n.a. & n.a. & $\mathrm{kg}$ \\
COD of feces & n.a. & n.a. & $\mathrm{kg}$ \\
COD of solids in the fish tanks & n.a. & n.a. & $\mathrm{kg}$ \\
COD of soluble excretion & n.a. & n.a. & $\mathrm{kg}$ \\
COD in RAS & n.a. & n.a. & $\mathrm{kg}$ \\
COD in RAS after fish sludge removal and refilling with groundwater & $m_{\mathrm{RAS}}^{\text {COD }}$ & n.a. & $\mathrm{kg}$ \\
COD to digester & $m_{\mathrm{RAS}}^{\text {COD }}$ & n.a. & $\mathrm{kg}$ \\
COD in RAS after dilution of RAS water and subsequent refilling with groundwater & $m_{\text {dig }}^{\text {COD }}$ & Eq. 24 & $\mathrm{~kg}$ \\
COD in RAS after HPS refill and subsequent refilling of RAS with groundwater & $m_{\mathrm{RAS}}^{\text {COD }}$ & n.a. & $\mathrm{kg}$. \\
Methane yield & n.a. & n.a. & $\mathrm{kg}$ \\
\hline
\end{tabular}

Table 13 Order in which calculation steps are taken to numerically solve the energy balance differential equation

\begin{tabular}{llll}
\hline Calculation step & Symbol & Equation & Unit \\
\hline Energy production by the generator & $p_{\text {gen }}^{E}$ & Eq. 27 & $\mathrm{kWh}$ \\
Energy requirement of heating inflowing groundwater in RAS & $Q_{g w}^{E}$ & Eq. 30 & $\mathrm{kWh}$ \\
Energy use of electronics in AP system & n.a. & n.a. & $\mathrm{kWh}$ \\
Total energy use of the system & n.a. & n.a. & $\mathrm{kWh}$ \\
Net energy yield & n.a. & n.a. & $\mathrm{kWh}$ \\
\hline
\end{tabular}




\section{Appendix D. Sensitivity analysis}

Table 14 Key performance indicator values and other system parameters under varying feed phosphorus content (1-2 wt \%), along with the corresponding normalized sensitivity coefficient (Eq. 4)

Table 15 Key performance indicator values and other system parameters under varying phosphorus mobilization rates of the anaerobic digester (10-95\%) for a P content of $1.5 \mathrm{wt} \%$, along with the corresponding normalized sensitivity coefficients (Eq. 4)

Table 16 Key performance indicator values and other system parameters under varying feed protein content, along with the corresponding sensitivity values

Table 17 Key performance indicator values and other system parameters under nitrogen mobilization rates of the anaerobic digester, along with the corresponding sensitivity values

\begin{tabular}{llllll}
\hline & \multicolumn{2}{l}{ P content } & & \\
\cline { 2 - 3 } Parameter & $1 \mathrm{wt} \%$ & $2 \mathrm{wt} \%$ & & Unit & \multicolumn{1}{l}{$S$} \\
\hline NUE N & 75.66 & 59.47 & & $\%$ & -0.368 \\
NUE P & 93.16 & 67.42 & & 0.501 \\
WUE & 96.04 & 48.02 & & -1.10 \\
Feeding rate ratio & 9.08 & 9.08 & $\mathrm{~g} \mathrm{~m}^{-2} \mathrm{~d}^{-1}$ & 0 \\
N in feed & 763 & 763 & $\mathrm{~kg}$ & 0 \\
P in feed & 136 & 272 & $\mathrm{~kg}$ & 1 \\
N supplemented & 0.151 & 64.691 & $\mathrm{~kg}$ & 641 \\
P supplemented & 0 & 0 & $\mathrm{~kg}$ & n.a. \\
\hline
\end{tabular}

\begin{tabular}{|c|c|c|c|c|}
\hline \multirow[b]{2}{*}{ Parameter } & \multicolumn{2}{|c|}{ P mobilization rate } & \multirow[b]{2}{*}{ Unit } & \multirow[b]{2}{*}{$S$} \\
\hline & $10 \%$ & $95 \%$ & & \\
\hline NUE N & 76.69 & 65.00 & $\%$ & -0.052 \\
\hline NUE P & 57.62 & 77.07 & $\%$ & 0.074 \\
\hline WUE & 99.54 & 62.36 & $\%$ & -0.168 \\
\hline Feeding rate ratio & 9.08 & 9.08 & $\mathrm{~g} \mathrm{~m}^{-2}$ day $^{-1}$ & 0 \\
\hline $\mathrm{N}$ in feed & 763 & 763 & $\mathrm{~kg}$ & 0 \\
\hline$P$ in feed & 204 & 204 & $\mathrm{~kg}$ & 0 \\
\hline $\mathrm{N}$ supplemented & 0.151 & 3.960 & $\mathrm{~kg}$ & 7712.990 \\
\hline P supplemented & 11 & 0 & $\mathrm{~kg}$ & n.a. \\
\hline
\end{tabular}

\begin{tabular}{llllll}
\hline & \multicolumn{2}{l}{ Protein content } & & \\
\cline { 2 - 3 } \cline { 5 - 6 } Parameter & $30 \%$ & $40 \%$ & & $S$ & Unit \\
\cline { 5 - 6 } & & & & \\
\hline NUE N & 65.93 & 66.27 & & 0.018 & $\%$ \\
NUE P & 77.00 & 77.00 & & 0 & $\%$ \\
WUE & 65.23 & 65.23 & & 0 & $\%$ \\
Feeding rate & 9.08 & 9.08 & & 0 & $\mathrm{~g} \mathrm{~m}^{-2}$ day $^{-1}$ \\
N in feed & 654 & 872 & & 1 & $\mathrm{~kg}$ \\
P in feed & 204 & 204 & & 0 & $\mathrm{~kg}$ \\
N supplemented & 21.62 & 0.036 & & -500 & $\mathrm{~kg}$ \\
P supplemented & 0 & 0 & & n.a. & $\mathrm{kg}$ \\
\hline
\end{tabular}

\begin{tabular}{|c|c|c|c|c|}
\hline \multirow[b]{2}{*}{ Parameter } & \multicolumn{2}{|c|}{$\mathrm{N}$ mobilization rate } & \multirow[b]{2}{*}{$S$} & \multirow[b]{2}{*}{ Unit } \\
\hline & $10 \%$ & $50 \%$ & & \\
\hline NUE N & 62.94 & 71.68 & 0.083 & $\%$ \\
\hline NUE P & 77.00 & 77.00 & 0 & $\%$ \\
\hline WUE & 65.23 & 65.23 & 0 & $\%$ \\
\hline Feeding rate & 9.08 & 9.08 & 0 & $\mathrm{~g} \mathrm{~m}^{-2}$ day $^{-1}$ \\
\hline $\mathrm{N}$ in feed & 763 & 763 & 0 & $\mathrm{~kg}$ \\
\hline $\mathrm{P}$ in feed & 204 & 204 & 0 & $\mathrm{~kg}$ \\
\hline $\mathrm{N}$ supplemented & 22.739 & 0 & $-94,118$ & $\mathrm{~kg}$ \\
\hline P supplemented & 0 & 0 & n.a. & $\mathrm{kg}$ \\
\hline
\end{tabular}


Table 18 Key performance indicator values and other system parameters under varying climate conditions

\begin{tabular}{|c|c|c|c|c|c|}
\hline \multirow[b]{2}{*}{ Parameter } & \multicolumn{2}{|c|}{ Relative humidity } & \multicolumn{2}{|c|}{ Temperature } & \multirow[b]{2}{*}{ Unit } \\
\hline & High & Low & High & Low & \\
\hline NUE N & 66.31 & 65.65 & 66.73 & 65.26 & $\%$ \\
\hline NUE P & 77.52 & 76.50 & 78.19 & 75.9 & $\%$ \\
\hline WUE & 66.24 & 64.26 & 67.53 & $63.09 \%$ & $\%$ \\
\hline Feeding rate & 9.08 & 9.08 & 9.08 & 9.08 & $\mathrm{~g} \mathrm{~m}^{-2}$ day $^{-1}$ \\
\hline Solar collector requirement & 6.8 & 6.6 & 6.9 & 6.5 & $\mathrm{~m}^{2}$ \\
\hline PV panel requirement & 78.1 & 78.1 & 78.1 & 78.0 & $\mathrm{~m}^{2}$ \\
\hline $\mathrm{N}$ in feed & 763 & 763 & 763 & 763 & $\mathrm{~kg}$ \\
\hline$P$ in feed & 204 & 204 & 204 & 204 & $\mathrm{~kg}$ \\
\hline $\mathrm{N}$ supplemented & 0.157 & 0.144 & 0.192 & 0.124 & $\mathrm{~kg}$ \\
\hline P supplemented & 0 & 0 & 0 & 0 & $\mathrm{~kg}$ \\
\hline
\end{tabular}

Table 19 Key performance indicator values and other system parameters under varying nitrogen metabolism parameters, along with the corresponding sensitivity values. It is indicated whether solid or soluble excretion is favored, compared to the nominal situation, along with the solid:soluble excretion ratio value

\begin{tabular}{lllll}
\hline & \multicolumn{2}{l}{ Nitrogen } & & \\
\cline { 2 - 4 } Parameter & $\begin{array}{l}\text { Soluble N } \\
(0.211)\end{array}$ & $\begin{array}{l}\text { Solid N } \\
(0.643)\end{array}$ & $S$ & Unit \\
\hline NUE N & 68.00 & 64.07 & -0.054 & $\%$ \\
NUE P & 77.00 & 77.00 & 0 & $\%$ \\
WUE & 65.23 & 65.23 & 0 & $\%$ \\
Feeding rate & 9.08 & 9.08 & 0 & $\mathrm{~g} \mathrm{~m}^{-2} \mathrm{day}^{-1}$ \\
N in feed & 763 & 763 & 0 & $\mathrm{~kg}$ \\
P in feed & 204 & 204 & 0 & $\mathrm{~kg}$ \\
N supplemented & 0.106 & 10.232 & 61,800 & $\mathrm{~kg}$ \\
P supplemented & 0 & 0 & n.a. & $\mathrm{kg}$ \\
\hline
\end{tabular}

Table 20 Key performance indicator values and other system parameters under varying phosphorus metabolism parameters, along with the corresponding sensitivity values. It is indicated whether solid or soluble excretion is favored, compared to the nominal situation, along with the solid:soluble excretion ratio

\begin{tabular}{lllll}
\hline & Phosphorus & & & \\
\hline Parameter & Soluble P & Solid P & $S$ & Unit \\
& $(1.25)$ & $(5.00)$ & & $\%$ \\
NUE N & 65.78 & 66.19 & 0.004 & $\%$ \\
NUE P & 77.10 & 76.89 & -0.002 & $\%$ \\
WUE & 64.70 & 65.85 & 0.010 & $\mathrm{~g} \mathrm{~m}^{-2} \mathrm{day}^{-1}$ \\
Feeding rate & 9.08 & 9.08 & 0 & $\mathrm{~kg}$ \\
N in feed & 763 & 763 & 0 & $\mathrm{~kg}$ \\
P in feed & 204 & 204 & 0 & $\mathrm{~kg}$ \\
N supplemented & 0.239 & 0.151 & -0.339 & n.a. \\
P supplemented & 0 & 0 & &
\end{tabular}


In Table 16, the effect of varying feed protein content on model output is shown. The uncertain protein content of fish feed does create negligible uncertainty in key performance indicators concerning sustainability, as reflected in the sensitivity values in Table 16. Supplementing of $\mathrm{N}$ in the nutrient solution is required when feed protein content is low.

Uncertainty caused by an uncertain nitrogen mobilization rate is shown in Table 17. Uncertainty of the N mobilization rate has a small impact on the NUE of N, as reflected by the sensitivity value. Furthermore, a higher mobilization rate completely removes the need for $\mathrm{N}$ supplementing.

Both variations in feed composition and variation in mobilization rates have no impact on the energy balance of the system; hence in Tables 14, 15, 16, and 17, the effect on solar collectors and PV panel surface requirements was not presented.

Relative humidity and temperature directly affect evapotranspiration rate and thereby have an impact on the system. Uncertainty in climate conditions does not have a significant effect on model outputs. High RH and high temperature result in a higher evapotranspiration rate, which leads to a higher WUE and higher NUE for both $\mathrm{N}$ and P. In the low-temperature scenario, evapotranspiration rate is lower, meaning less water has to move from the RAS to the HPS. Therefore, less groundwater needs to flow into the RAS, explaining a lower solar collector requirement. Given that less water moves from the RAS to the HPS, more COD is present in RAS water, meaning more COD will flow to the digester. This higher COD concentration results in slightly higher methane yield, reducing the requirement for solar panels by $0.1 \mathrm{~m}^{2}$ compared with the nominal situation.

Uncertainty in fish metabolism parameters has no impact on the energy balance of the system; hence, there is no mention of the solar collector and PV panel surface requirement in Table 19 and Table 20. When soluble excretion of either nutrient is favored, NUE is higher. This observation can be explained by the fact that part of the solid excretion is lost in the waste sludge of the digester. Since the mobilization rate of $\mathrm{P}$ in the anaerobic digester is higher, the effect of an uncertain solid:soluble excretion ratio on the NUE of $\mathrm{P}$ is lower. When solid excretion of $\mathrm{N}$ is favored, supplementing of $\mathrm{N}$ is 100 times the amount of when soluble excretion of $\mathrm{N}$ is favored. The reason for this is that more solid excretion of $\mathrm{N}$ leads to more loss of $\mathrm{N}$ in the waste sludge of the anaerobic digester. Less $\mathrm{N}$ will flow into the nutrient solution, increasing the requirement for supplementing. When soluble excretion of $\mathrm{P}$ is favored, WUE is lower and the amount of $\mathrm{N}$ supplement is higher. If soluble excretion of $\mathrm{P}$ is favored, the concentration of $\mathrm{P}$ in RAS water is higher, and the concentration of $\mathrm{P}$ in the effluent is lower, compared with the situation where solid excretion of $\mathrm{P}$ is favored. Overall, this leads to slightly more $\mathrm{P}$ flowing into the nutrient solution, leading to a higher dilution requirement of the nutrient solution, and thus a higher supplementing requirement of N. Furthermore, the effect of an uncertain solid:soluble excretion ratio of both nitrogen and phosphorus on the model outputs is small compared with the effect of uncertain feed contents, as reflected by the sensitivity values. 


\section{Appendix E. Additional model outputs}

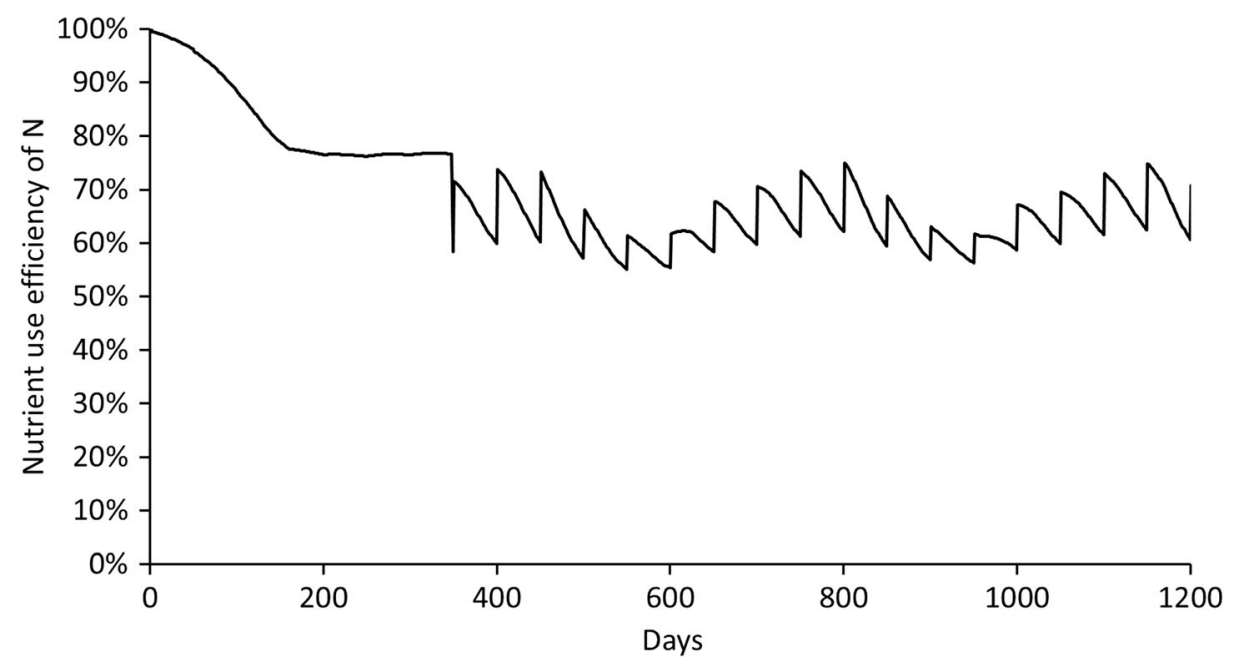

Fig. 6 Nutrient use efficiency of nitrogen in the DAPS of the Kikaboni farm

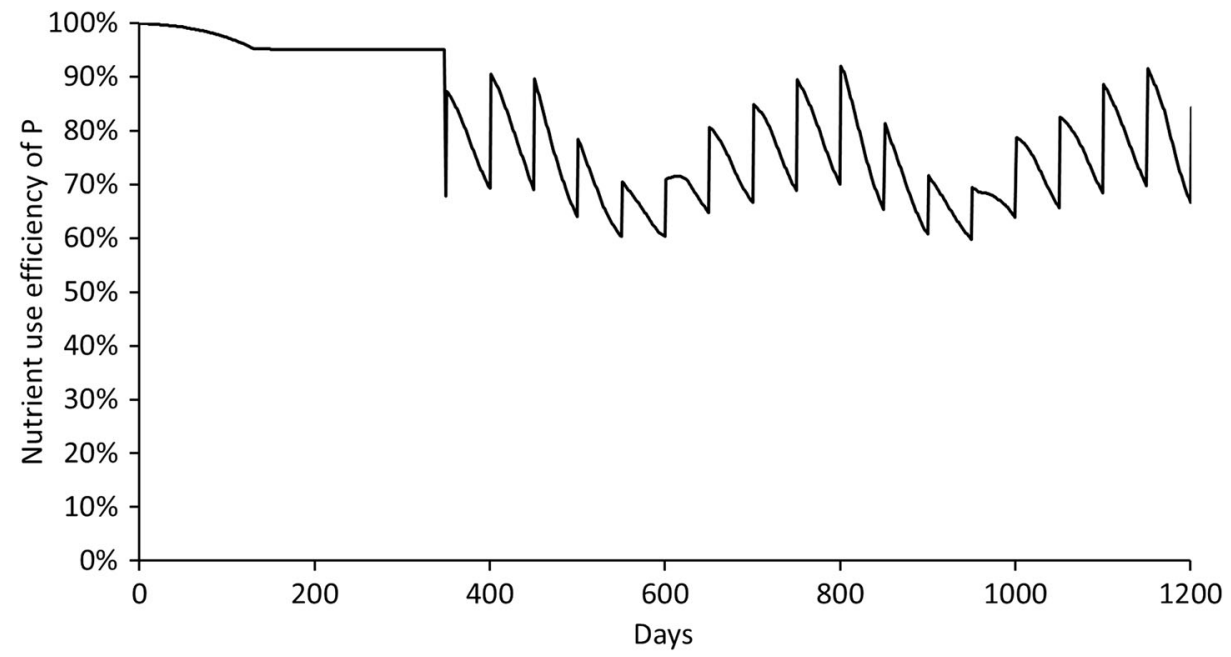

Fig. 7 Nutrient use efficiency of phosphorus in the DAPS of the Kikaboni farm

NUE of both $\mathrm{N}$ and P, respectively shown in Fig. 6 and Fig. 7, decreases in the first 200 days, of which the decrease rate is highest in the first 160 days. This observation can be explained by the fact that the amount of nutrients lost in waste sludge increases until it reaches a maximum at day 200, at which point fish are harvested and feed input drops down. Supplementing $\mathrm{N}$ to the nutrient solution stops at approx. day 160, as seen in Fig. 3, explaining why NUE of $\mathrm{N}$ decreases at a lower rate from this day on. Supplemented nutrients are not wasted, whereas nutrients added through fish feed are partly wasted as waste sludge of the anaerobic digester. The same principle applies to NUE of P, where supplementing $\mathrm{P}$ to the 
nutrient solution stops at $\sim$ day 130, as seen in Fig. 4, from which day on NUE P decreases at a lower rate.

At approx. day 350, dilution of the nutrient solution starts to occur, causing the NUE of both $\mathrm{N}$ and $\mathrm{P}$ to drop. A 50-day pattern can also be seen in both the NUE of $\mathrm{N}$ and P. NUE steadily decreases, and after 50 days it instantly increases to a maximum, after which it starts steadily decreasing again. This observation is explained by the fact that after fish harvesting, the nutrient input drops down, reducing the need for dilution of the nutrient solution. Furthermore, a 365-day pattern can be seen in both the NUE curve of $\mathrm{N}$ and P. When the evapotranspiration is low, the NUE is also low, due to the fact that nutrients flowing out of the system in evapotranspiration water are not considered as wasted nutrients. If the evapotranspiration rate is low, dilution requirement is high.

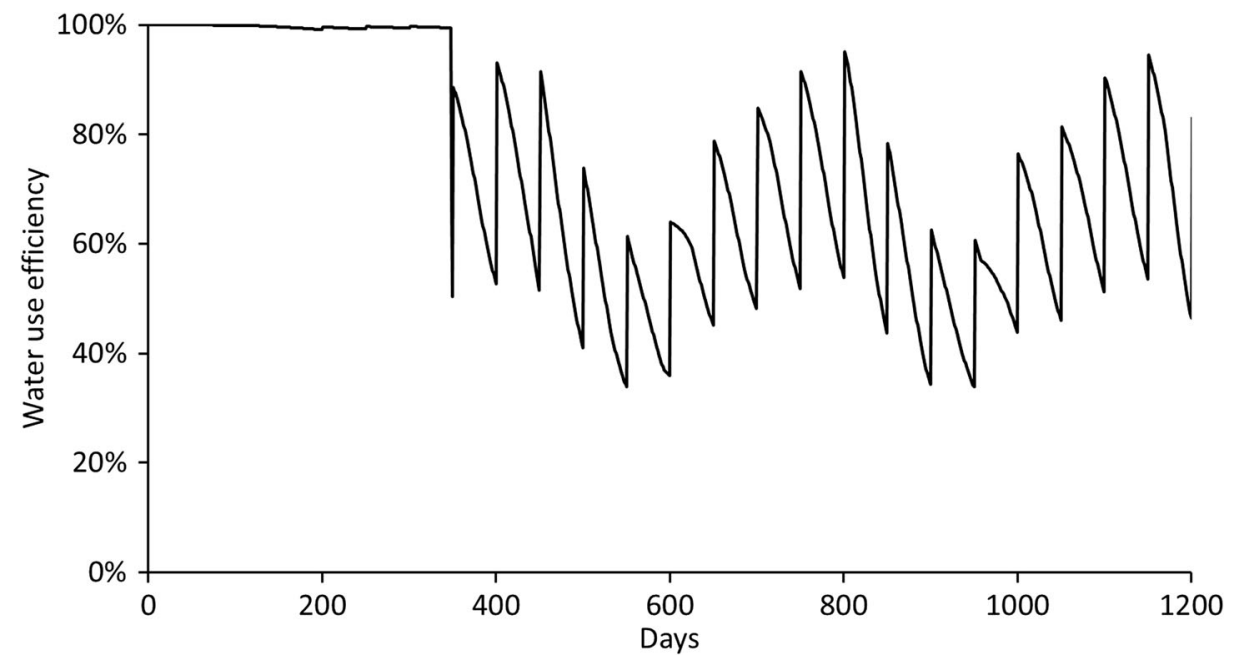

Fig. 8 Water use efficiency in the DAPS of the Kikaboni farm

Previously explained principles also explain the WUE behavior from approx. day 350 on (Fig. 8). The slight variations seen in the first 350 days are explained by water lost in the waste sludge of the anaerobic digester. Water lost in the waste sludge of the anaerobic digester follows the 50-day pattern caused by the amount of feed input, reaching a maximum when feed input is at its highest point.

Open Access This article is distributed under the terms of the Creative Commons Attribution 4.0 International License (http://creativecommons.org/licenses/by/4.0/), which permits unrestricted use, distribution, and reproduction in any medium, provided you give appropriate credit to the original author(s) and the source, provide a link to the Creative Commons license, and indicate if changes were made.

\section{References}

Allen RG, Pereira LS, Raes D et al (1998) Crop evapotranspiration - guidelines for computing crop water requirements - FAO irrigation and drainage. Irrig Drain 56:1-15. https://doi.org/10.1016/j.eja.2010.12.001 Chernicharo C (2007) Anaerobic Reactors. IWA, London 
Cordell D, Drangert JO, White S (2009) The story of phosphorus: global food security and food for thought. Glob Environ Chang 19:292-305. https://doi.org/10.1016/j.gloenvcha.2008.10.009

Craig S, Helfrich L (2002) Understanding fish nutrition, feeds, and feeding. Virginia Coop Ext 1-18. https://pubs. ext.vt.edu/420/420-256/420-256.html

de Mes TZD, Stams AJM, Reith JH, Zeeman G (2003) Methane production by anaerobic digestion of wastewater and solid wastes. Bio-methane bio-hydrogen. Status Perspect Biol methane Hydrog Prod 102:58-102. https://doi.org/10.1016/j.biortech.2010.08.032

Delaide et al. (2018) A methodology to quantify the aerobic and anaerobic sludge digestion performance for nutrient recycling in aquaponics. Biotechnol Agron Soc Environ 22(2):106-112

DeLong DP, Losordo T, Rakocy J (2009) Tank culture of tilapia. https://appliedecology.cals.ncsu.edu/wpcontent/uploads/282.pdf. Accessed 24 Sep 2018

Eck, M, Körner O, Jijakli MH (2019) Nutrient cycling in aquaponics systems. In: S Goddek, A Joyce, B Kotzen, and G Burnell. Aquaponics food production systems - combined aquaculture and hydroponic production technologies for the future. Springer International Publishing

El-Sayed A-FM (2006) Tilapia culture. CABI, Wallingford

Endut A, Jusoh A, Ali N, Wan Nik WB, Hassan A (2010) A study on the optimal hydraulic loading rate and plant ratios in recirculation aquaponic system. Bioresour Technol 101:1511-1517. https://doi.org/10.1016/j. biortech.2009.09.040

FAO (2018) FAO global aquaculture production statistics database updated to 2016: aquaculture feed and fertilizer resources information system. Food Agric Organ United Nations 2016

Gebauer R (2004) Mesophilic anaerobic treatment of sludge from saline fish farm effluents with biogas production. Bioresour Technol 93:155-167. https://doi.org/10.1016/j.biortech.2003.10.024

Gebauer R, Eikebrokk B (2006) Mesophilic anaerobic treatment of sludge from salmon smolt hatching. Bioresour Technol 97:2389-2401. https://doi.org/10.1016/j.biortech.2005.10.008

Goddek S, Keesman KJ (2018) The necessity of desalination technology for designing and sizing multi-loop aquaponics systems. Desalination 428:76-85. https://doi.org/10.1016/j.desal.2017.11.024

Goddek \& Vermeulen (2018) Comparison of Lactuca sativa growth performance in conventional and RAS-based hydroponic systems. Aquac Int 26(6):1377-1386

Goddek S, Körner O (May 1, 2019) A fully integrated simulation model of multi-loop aquaponics: a case study for system sizing in different environments. Agric Syst 171:143-154. https://doi.org/10.1016/j. agsy.2019.01.010

Goddek S, Schmautz Z, Scott B, Delaide B, Keesman K, Wuertz S, Junge R (2016) The effect of anaerobic and aerobic fish sludge supernatant on hydroponic lettuce. Agronomy 6:37. https://doi.org/10.3390 /agronomy6020037

Goddek et al. (2018) Nutrient mineralization and organic matter reduction performance of RAS-based sludge in sequential UASB-EGSB reactors. Aquac Eng 83:10-19

Jamar A, Majid ZAA, Azmi WH, Norhafana M, Razak AA (2016) A review of water heating system for solar energy applications. Int Commun Heat Mass Transf 76:178-187. https://doi.org/10.1016/j. icheatmasstransfer.2016.05.028

Jones J (2004) A practical guide for the soilless grower. Hydroponics. https://doi.org/10.1201/9781420037708

Jung IS, Lovitt RW (2011) Leaching techniques to remove metals and potentially hazardous nutrients from trout farm sludge. Water Res 45:5977-5986. https://doi.org/10.1016/j.watres.2011.08.062

Karimanzira D, Keesman KJ, Kloas W, Baganz D, Rauschenbach T (2016) Dynamic modeling of the INAPRO aquaponic system. Aquac Eng 75:29-45. https://doi.org/10.1016/j.aquaeng.2016.10.004

Kloas W, Groß R, Baganz D, Graupner J, Monsees H, Schmidt U, Staaks G, Suhl J, Tschirner M, Wittstock B, Wuertz S, Zikova A, Rennert B (2015) A new concept for aquaponic systems to improve sustainability, increase productivity, and reduce environmental impacts. Aquac Environ Interact 7:179-192. https://oi. org/10.3354/aei00146

Lanari D, Franci C (1998) Biogas production from solid wastes removed from fish farm effluents. Aquat Living Resour 11:289-295. https://doi.org/10.1016/S0990-7440(98)80014-4

Lennard W (2012) Aquaponic system design parameters : fish to plant ratios (feeding rate ratios). Aquaponic Solut 1:1-11

Letey J, Jarrell WM, Valoras N (1982) Nitrogen and water uptake patterns and growth of plants at various minimum solution nitrate concentrations. J Plant Nutr 5:73-89. https://doi.org/10.1080 /01904168209362939

Meriac A (2014) Dietary carbohydrates and denitrification in recirculating aquaculture systems. Wageningen University, Wageningen

Mirzoyan N, Tal Y, Gross A (2010) Anaerobic digestion of sludge from intensive recirculating aquaculture systems: review. Aquaculture 306:1-6 
Neto R, Ostrensky A (2015) Nutrient load estimation in the waste of Nile tilapia Oreochromis niloticus (L.) reared in cages in tropical climate conditions. Aquac Res 46:1309-1322. https://doi.org/10.1111/are.12280

Onyango AO, Ongoma V (2015) Estimation of mean monthly global solar radiation using sunshine hours for Nairobi City, Kenya. J Renew Sustain Energy 7. https://doi.org/10.1063/1.4930530

Palm HW, Seidemann R, Wehofsky S, Knaus U (2014) Significant factors affecting the economic sustainability of closed aquaponic systems. Part I: system design, chemo-physical parameters and general aspects. AACL Bioflux 7(1):20-32

Palm HW, Knaus U, Appelbaum S, Goddek S, Strauch SM, Vermeulen T, Haïssam Jijakli M, Kotzen B (2018) Towards commercial aquaponics: a review of systems, designs, scales and nomenclature. Aquac Int 26(3): 813-842

Qadir M, Sharma BR, Bruggeman A, Choukr-Allah R, Karajeh F (2007) Non-conventional water resources and opportunities for water augmentation to achieve food security in water scarce countries. Agric Water Manag 87:2-22

Qiu R, Kang S, Du T et al (2013) Effect of convection on the Penman-Monteith model estimates of transpiration of hot pepper grown in solar greenhouse. Sci Hortic (Amsterdam) 160:163-171. https://doi.org/10.1016/j. scienta.2013.05.043

Ragnarsdottir KV, Sverdrup HU, Koca D (2011) Challenging the planetary boundaries I: basic principles of an integrated model for phosphorous supply dynamics and global population size. Appl Geochem 26:S303S306. https://doi.org/10.1016/j.apgeochem.2011.03.088

Rakocy JE, Shultz RC, Bailey DS, Thoman ES (2004) Aquaponic production of tilapia and basil: comparing a batch and staggered cropping system. Acta Hortic:63-69

Rakocy JE, Masser MP, Losordo TM (2006) Recirculating aquaculture tank production systems: aquaponicsintegrating fish and plant culture. SRAC Publ - South Reg Aquac Cent 16:454

Rakocy JE, Bailey DS, Shultz RC, Danaher JJ (2007) Preliminary evaluation of organic waste from two aquaculture systems as a source of inorganic nutrients for hydroponics. In: Acta Horticulturae, pp 201-207

Resh HM (2015) Hydroponics for the home grower. CRC Press

Reyes Lastiri D, Slinkert T, Cappon HJ, Keesman KJ (2016) Model of an aquaponic system for minimised water, energy and nitrogen requirements. Water Sci Technol 74:30-37. https://doi.org/10.2166/wst.2016.127

Reyes Lastiri D, Geelen C, Cappon H, Rijnaarts HHM, Baganz D, Kloas W, Karimanzira D, Keesman KJ (2018) Model-based management strategy for resource efficient design and operation of an aquaponic system. Aquac Eng 83:27-39. ISSN 0144-8609

Ross LG (2000) Environmental physiology and energetics. Tilapias Biol Exploit:89-128. https://doi.org/10.1007 1978-94-011-4008-9 4

Santos BM, Dusky JA, Stall WM, Bewick TA, Shilling DG, Gilreath JP (2004) Phosphorus absorption in lettuce, smooth pigweed (Amaranthus hybridus), and common purslane (Portulaca oleracea) mixtures. Weed Sci 52: 389-394

Schmautz Z, Loeu F, Liebisch F, Graber A, Mathis A, Griessler Bulc T, Junge R (2016) Tomato productivity and quality in aquaponics: comparison of three hydroponic methods. Water (Switzerland) 8. https://doi. org/10.3390/w8110533

Sonneveld C, Voogt W (2009) Plant nutrition of greenhouse crops. Springer Netherlands, Dordrecht

Suhl J, Dannehl D, Kloas W, Baganz D, Jobs S, Scheibe G, Schmidt U (2016) Advanced aquaponics: evaluation of intensive tomato production in aquaponics vs. conventional hydroponics. Agric Water Manag 178:335344. https://doi.org/10.1016/j.agwat.2016.10.013

Timmons MB, Ebeling JM (2010) Aquaculture Production Systems, 3rd edn. Ithaca Publishing Company, Ithaca

Tomovic R (1963) Sensitivity analysis of dynamic systems. McGraw-Hill, New York

Touliatos D, Dodd IC, Mcainsh M (2016) Vertical farming increases lettuce yield per unit area compared to conventional horizontal hydroponics. Food Energy Secur 5:184-191. https://doi.org/10.1002/fes3.83

UN (2012) The future we want: outcome document of the United Nations Conference on Sustainable Development

WorldWeatherOnline (2017) Nairobi Monthly Climate Averages. https://www.worldweatheronline.com/nairobiweather-averages/nairobi-area/ke.aspx. Accessed 7 Mar 2018

Yogev U, Barnes A, Gross A (2016) Nutrients and energy balance analysis for a conceptual model of a three loops off-grid, aquaponics. Water (Switzerland) 8. https://doi.org/10.3390/w8120589

Zolnier GBL, Gates RS (2004) Evapotranspiration estimates for greenhouse lettuce using an intermittent nutrient film technique. Trans ASAE 47:271-282. https://doi.org/10.13031/2013.15868

Publisher's note Springer Nature remains neutral with regard to jurisdictional claims in published maps and institutional affiliations. 